\title{
Precipitation products from the hydrology SAF
}

\author{
A. Mugnai ${ }^{1}$, D. Casella ${ }^{1}$, E. Cattani ${ }^{1}$, S. Dietrich ${ }^{1}$, S. Laviola ${ }^{1}$, V. Levizzani ${ }^{1}$, G. Panegrossi ${ }^{1}$, M. Petracca ${ }^{1}$, P. Sanò ${ }^{1}$, \\ F. Di Paola ${ }^{2}$, D. Biron ${ }^{3}$, L. De Leonibus ${ }^{3}$, D. Melfi ${ }^{3}$, P. Rosci ${ }^{3}$, A. Vocino ${ }^{3}$, F. Zauli ${ }^{3}$, P. Pagliara ${ }^{4}$, S. Puca ${ }^{4}$, A. Rinollo ${ }^{4}$, \\ L. Milani ${ }^{5}$, F. Porcù ${ }^{5}$, and F. Gattari ${ }^{6}$ \\ ${ }^{1}$ Istituto di Scienze dell'Atmosfera e del Clima (ISAC), Consiglio Nazionale delle Ricerche (CNR), Bologna-Roma, Italy \\ ${ }^{2}$ Istituto di Metodologie ed Analisi Ambientali (IMAA), Consiglio Nazionale delle Ricerche (CNR), Tito Scalo, Italy \\ ${ }^{3}$ Centro Nazionale di Meteorologia e Climatologia Aeronautica (CNMCA), Ufficio Generale Spazio Aereo e Meteorologia \\ (USAM), Aeronautica Militare Italiana (ITAF), Pratica di Mare, Italy \\ ${ }^{4}$ Dipartimento della Protezione Civile (DPC), Presidenza del Consiglio dei Ministri, Roma, Italy \\ ${ }^{5}$ Dipartimento di Fisica, Università di Ferrara, Ferrara, Italy \\ ${ }^{6}$ Telespazio, Roma, Italy
}

Correspondence to: A. Mugnai (alberto.mugnai@artov.isac.cnr.it)

Received: 11 November 2012 - Published in Nat. Hazards Earth Syst. Sci. Discuss.: -

Revised: 26 April 2013 - Accepted: 14 May 2013 - Published: 6 August 2013

\begin{abstract}
The EUMETSAT Satellite Application Facility on Support to Operational Hydrology and Water Management (H-SAF) was established by the EUMETSAT Council on 3 July 2005, starting activity on 1 September 2005 . The Italian Meteorological Service serves as Leading Entity on behalf of twelve European member countries. H-SAF products include precipitation, soil moisture and snow parameters. Some products are based only on satellite observations, while other products are based on the assimilation of satellite measurements/products into numerical models. In addition to product development and generation, H-SAF includes a product validation program and a hydrological validation program that are coordinated, respectively, by the Italian Department of Civil Protection and by the Polish Institute of Meteorology and Water Management. The National Center of Aeronautical Meteorology and Climatology (CNMCA) of the Italian Air Force is responsible for operational product generation and dissemination.

In this paper we describe the H-SAF precipitation algorithms and products, which have been developed by the Italian Institute of Atmospheric Sciences and Climate (in collaboration with the international community) and by CNMCA during the Development Phase (DP, 2005-2010) and the first Continuous Development and Operations Phase (CDOP1, 2010-2012). The precipitation products are based on passive microwave measurements obtained from radiometers onboard different sun-synchronous low-Earth-orbiting satellites (especially, the SSM/I and SSMIS radiometers
\end{abstract}

onboard DMSP satellites and the AMSU-A + AMSUB/MHS radiometer suites onboard EPS-MetOp and NOAAPOES satellites), as well as on combined infrared/passive microwave measurements in which the passive microwave precipitation estimates are used in conjunction with SEVIRI images from the geostationary MSG satellite. Moreover, the $\mathrm{H}-\mathrm{SAF}$ product generation and dissemination chain and independent product validation activities are described. Also, the H-SAF program and its associated activities that currently are being carried out or are planned to be performed within the second CDOP phase (CDOP-2, 2012-2017) are presented in some detail. Insofar as CDOP-2 is concerned, it is emphasized that all algorithms and processing schemes will be improved and enhanced so as to extend them to satellites that will be operational within this decade - particularly the geostationary Meteosat Third Generation satellites and the low-Earth-orbiting Core Observatory of the international Global Precipitation Measurement mission. Finally, the role of H-SAF within the international science and operations community is explained.

\section{Introduction}

In 1992 the European Organisation for the Exploitation of Meteorological Satellites (EUMETSAT) adopted the concept of a Distributed Application Ground Segment, which would include the Central Facility, located at the EUMETSAT 


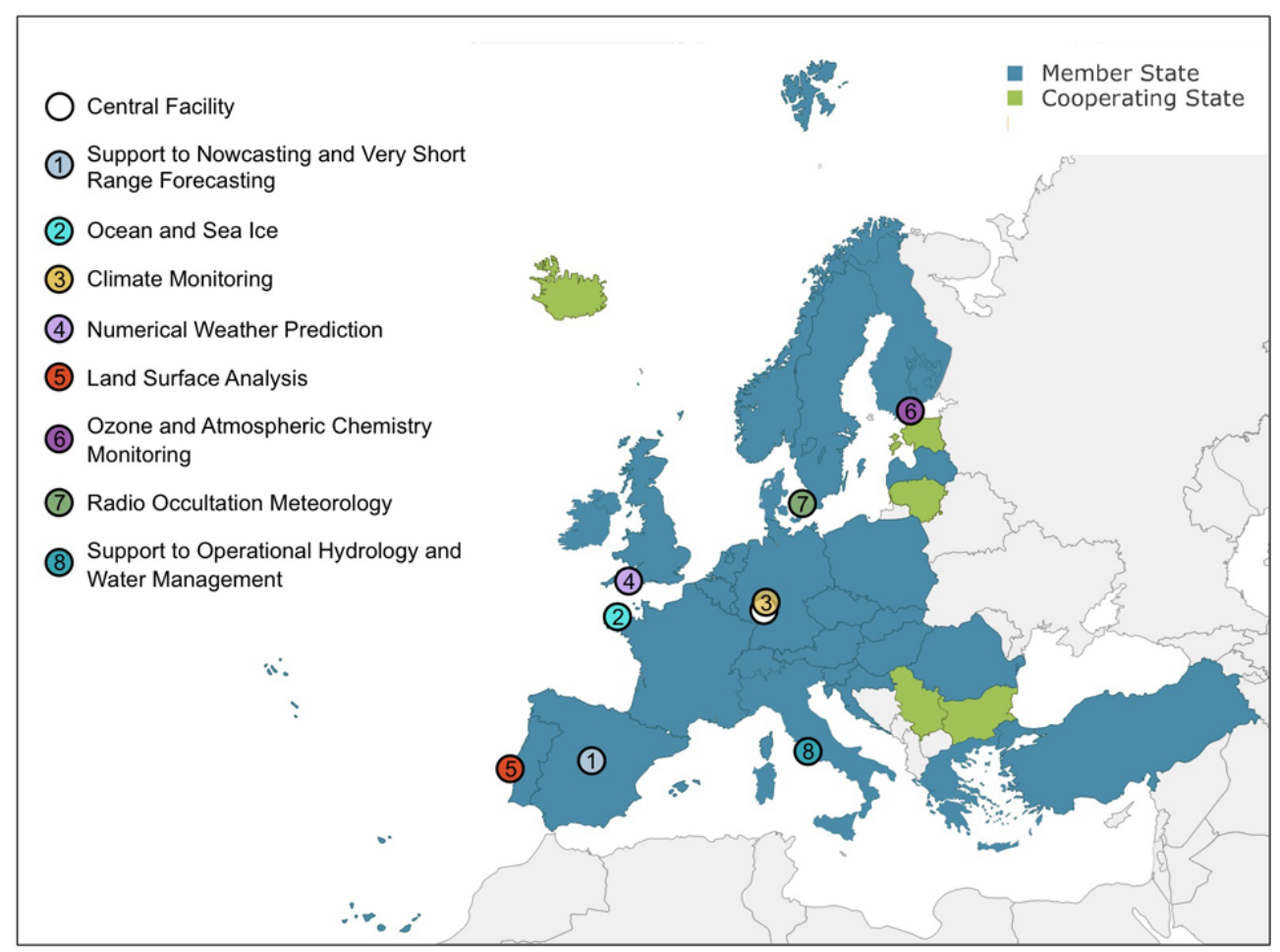

Fig. 1. EUMETSAT's network of the current eight Satellite Application Facilities (SAFs). The colored circles identifying the various SAFs have been placed in correspondence to the locations of their leading entities, whereas the white circle identifying the Central Facility has been placed in correspondence to EUMETSAT's headquarters in Darmstadt, Germany. (Adapted from EUMETSAT: http://www.eumetsat. int/website/home/AboutUs/WhoWeAre/MemberStates/index.html.)

Headquarters in Darmstadt, Germany, and a network of elements known as Satellite Application Facilities (SAFs). The SAFs are specialized development and processing centers which utilize specific expertise available in EUMETSAT's Member and Cooperating States to develop and deliver satellite products to international research and operations users. On this basis, a SAF Network has been set up, developed by consortia of organizations from within the EUMETSAT Member and Cooperating States and located at the national meteorological services in Member States, which complements the production of standard meteorological products derived from satellite data at the central facilities in Darmstadt. The SAF Network also distributes user software packages.

The main objectives of the SAF Network can be summarized as follows: (1) improve capabilities of EUMETSAT's Member States to exploit satellite data; (2) encourage utilization of existing skills and infrastructure in Member and Cooperating States; and (3) facilitate cost-effective exploitation by ensuring that services are optimally distributed.

Currently there are eight SAFs, all of which provide products and services on an operational basis, each one dedicated to a specific discipline within operational meteorology, climatology and earth observation (see Fig. 1). Each SAF is led by the national meteorological service of a EUMETSAT
Member State, and is executed in association with a consortium of EUMETSAT Member States and Cooperating States, government bodies and research institutes. The various SAFs were established at different times between 1997 and 2005 and started their activities with a Development Phase (DP), which usually lasted five years. In some cases, the DP phase was followed by an Initial Operations Phase (IOP), which lasted two to five years. The activities are now continuing with Continuous Development and Operations Phases (CDOPs), which are structured in five-yearly segments. For most SAFs the first CDOP phase (CDOP-1) started in early 2007. All SAFs entered the second CDOP phase (CDOP2) contemporarily in March 2012. For more information on the SAF Network, see the website http://www.eumetsat.int/ website/home/Satellites/GroundSegment/Safs/index.html.

The Satellite Application Facility on Support to Operational Hydrology and Water Management (H-SAF, or Hydrology SAF) is one of the current eight SAFs. It was established by the EUMETSAT Council on 3 July 2005, then initiated its DP activities on 1 September 2005 as a response to (1) a growing interest within the European Union (EU) in the steadily improving quality of operational and research satellite data; (2) the improving capabilities in hydrological remote sensing science; (3) the improving performances of hydrological models and the hydrological components 
of weather and climate prediction models; (4) the increasing need for global and reliable information on available water resources, recognized by international bodies and organizations; and finally (5) the improving techniques for assimilating hydrological observations into prediction models, particularly satellite retrieval observations.

In this paper, which is an extension and update of a Conference Proceedings paper prepared by Panegrossi et al. (2012), we first describe the H-SAF project (Sect. 2) with special emphasis on the activities that are being carried out within or are planned for the second CDOP phase that will cover the 2012-2017 five-year span, as well as on the present and expected role of H-SAF within the broader international community. Then we describe in some detail the six precipitation algorithms/products (Sect. 3) which have been developed by the Institute of Atmospheric Sciences and Climate (ISAC) of the Italian National Research Council (CNR) in collaboration with the international community and by the National Center of Aeronautical Meteorology and Climatology (CNMCA) of the Italian Air Force (ITAF) during the DP (2005-2010) and CDOP-1 (2010-2012) phases. Finally, we describe the product generation and dissemination chain that has been developed by and implemented at CNMCA (Sect. 4), and provide basic information concerning the H-SAF precipitation product validation (PPV) and hydrological validation (HV) activities (Sect. 5) that are coordinated, respectively, by the Italian Department of Civil Protection (DPC) and by the Polish Institute of Meteorology and Water Management (IMGW).

\section{H-SAF project}

In 2000 EUMETSAT began various steps towards the establishment of a SAF on support to hydrology. First, a specific "Working Group on a Potential SAF" was established, which after two years (2001-2002) consolidated the necessary hydrological end user requirements and decided a list of objectives that would be achievable within a five-year term. Then, a "SAF Hydrology Framework Working Group" was established, which operated for two additional years (2003-2004) and defined a scientific strategy and a long-term vision appropriate for a SAF on support to hydrology. In 2005, the Italian Air Force Meteorological Service set up a consortium for the H-SAF project, gathering institutions of ten countries (Austria, Belgium, Finland, France, Germany, Hungary, Italy, Poland, Slovakia, and Turkey) and one international agency, the European Centre for Medium-Range Weather Forecasts (ECMWF). The H-SAF Consortium submitted a proposal to EUMETSAT for the 2005-2010 DP phase, which was approved by the EUMETSAT Council on 3 July 2005. The DP activities started on 1 September 2005, ending successfully after five years, at which time H-SAF joined the other seven SAFs in the CDOP-1 phase.

Since the beginning, the overall H-SAF objectives have been to
1. provide new satellite-derived products from existing and future satellites with sufficient time and space resolution to satisfy the needs of operational hydrology, by means of the following identified products:

- precipitation (surface rate and accumulated, liquidsolid discrimination);

- soil moisture (at large scale, at local scale, at surface, in root zone);

- snow parameters (detection, cover, melting conditions, water equivalent).

2. perform independent validation of the usefulness of new products for mitigating against hazards due to floods, landslides and avalanches, as well as for evaluating water resources. Corresponding activities include

- downscaling/upscaling modeling from observed/predicted fields to basin level;

- fusion of satellite-derived measurements with data from radar and rain gauge networks;

- assimilation of satellite-derived products into hydrological models.

3. perform impact assessments of new satellite-derived products on hydrological applications.

During the DP phase, which covered $5 \mathrm{yr}$ until $31 \mathrm{Au}-$ gust 2010, H-SAF followed a stepwise developmental approach, according to which products started to be developed on the basis of available algorithms, databases and instruments, while a first release of several products were ready for evaluation at the mid-term of the DP phase. Thereafter, these products continued to be improved, with other ones added, on the basis of improved algorithms, databases and instruments, as well as of the results of calibration/validation activities. The distribution of several initial versions of products was achieved to allow end users, specifically hydrologists, to start evaluation and build-up impact study projects.

As soon as the DP phase ended, the CDOP-1 phase started, during which another member (Bulgaria) joined the H-SAF Consortium. CDOP-1 lasted only eighteen months so as to synchronize H-SAF with the other seven SAFs that had started their five-year CDOP-1 phase in early 2007. During CDOP-1, H-SAF operations with and dissemination of several products began in conjunction with the development and improvement of the entire suite of DP products. In March 2012, H-SAF entered, together with the other SAFs, the CDOP-2 phase, which will continue until February 2017 - see Sect. 2.2 for a detailed presentation of CDOP-2 activities.

\subsection{H-SAF Consortium structure}

The H-SAF is structured through a consortium of twenty cooperating and/or participating entities representing eleven 
Table 1. Composition of H-SAF Consortium (organized in alphabetical order of participating countries).

\begin{tabular}{|c|c|c|c|}
\hline Country & Institution & Acronym & Role in project \\
\hline Austria & $\begin{array}{l}\text { Central Institution for Meteorology and } \\
\text { Geodynamics }\end{array}$ & ZAMG & Leader for soil moisture \\
\hline Austria & $\begin{array}{l}\text { Vienna University of Technology, De- } \\
\text { partment for Geodesy and Geoinforma- } \\
\text { tion }\end{array}$ & TU-Wien & Contributor to soil moisture \\
\hline Belgium & Royal Meteorological Institute & IRM & $\begin{array}{l}\text { Contributor to validation and hydrovalidation } \\
\text { services }\end{array}$ \\
\hline Bulgaria & $\begin{array}{l}\text { National Institute of Meteorology and } \\
\text { Hydrology }\end{array}$ & NIMH & $\begin{array}{l}\text { Contributor to validation and hydrovalidation } \\
\text { services }\end{array}$ \\
\hline Finland & Finnish Meteorological Institute & FMI & Leader for snow \\
\hline France & Météo-France & Météo-France & $\begin{array}{l}\text { Contributor to validation and hydrovalidation } \\
\text { services }\end{array}$ \\
\hline Germany & Federal Institute of Hydrology & BfG & $\begin{array}{l}\text { Contributor to validation and hydrovalidation } \\
\text { services }\end{array}$ \\
\hline Hungary & Hungarian Meteorological Service & OMSZ & Contributor to validation services \\
\hline International & $\begin{array}{l}\text { European Centre for Medium-Range } \\
\text { Weather Forecasts }\end{array}$ & ECMWF & Contributor to "core" soil moisture \\
\hline Italy & $\begin{array}{l}\text { Meteorological Service of the Italian } \\
\text { Air Force }\end{array}$ & $\begin{array}{l}\text { ITAF SMA-USAM/ } \\
\text { ITAF CNMCA }\end{array}$ & Leading Institute + leader for precipitation \\
\hline Italy & Department of Civil Protection & DPC & Leader of product validation programme \\
\hline Italy & Telespazio & TPZ & $\begin{array}{l}\text { Industrial Firm, contributor to engineering } \\
\text { and project control }\end{array}$ \\
\hline Italy & $\begin{array}{l}\text { Italian National Research Council, In- } \\
\text { stitute of Atmospheric Sciences and } \\
\text { Climate }\end{array}$ & CNR-ISAC & Contributor to precipitation \\
\hline Italy & $\begin{array}{l}\text { Ferrara University, Department of } \\
\text { Physics }\end{array}$ & UNIFe & Contributor to precipitation \\
\hline Poland & $\begin{array}{l}\text { Institute of Meteorology and Water } \\
\text { Management }\end{array}$ & IMGW & Leader of hydrology programme \\
\hline Slovakia & Slovak Hydrometeorological Institute & SHMÚ & $\begin{array}{l}\text { Contributor to validation and hydrovalidation } \\
\text { services }\end{array}$ \\
\hline Turkey & Turkish State Meteorological Service & TSMS & Contributor to "core" snow \\
\hline Turkey & Anadolu University & AU & Contributor to snow \\
\hline Turkey & $\begin{array}{l}\text { Istanbul Technical University, Meteoro- } \\
\text { logical Department }\end{array}$ & ITU & Contributor to snow \\
\hline Turkey & $\begin{array}{l}\text { Middle East Technical University, Civil } \\
\text { Engineering Department }\end{array}$ & METU & Contributor to snow \\
\hline Turkey & Ondokuz Mayis University & OMU & Contributor to validation \\
\hline
\end{tabular}

European countries (Austria, Belgium, Bulgaria, Finland, France, Germany, Hungary, Italy, Poland, Slovakia, and Turkey) as well as ECMWF, led by the Italian Meteorological Service which provides the Coordination and Central Functions from Rome and Pratica di Mare - i.e., from ITAF's headquarters of the Aeronautical Meteorological Service (SMA) of the General Office for Air Space and Meteorology (USAM) and from ITAF's CNMCA (i.e., the Italian National Meteorological Center), respectively. The list of participating Institutes is given in Table 1 together with their roles in the $\mathrm{H}-\mathrm{SAF}$ project.

Notably, the role of the participating institutions reflects the overall technical and organizational architecture of the project, which is based on
- the Product Development and Generation Area, distributed among five operational centers - the Italian CNMCA for precipitation, the Austrian Central Institution for Meteorology and Geodynamics (ZAMG) and ECMWF for soil moisture, and the Finnish Meteorological Institute (FMI) and the Turkish State Meteorological Service (TSMS) for snow;

- the User Area, composed of two clusters, one for the product validation (PV) program, coordinated by Italian DPC, and the other for the hydrological validation (HV) program, coordinated by Polish IMGW.

We note that whereas the product generation activity is being performed by meteorological services supported by scientific 
institutes specializing in remote sensing, the product validation and hydrological validation programs are being performed by hydrometeorological services, hydrological scientific institutes, and operational units responsible for civil protection.

\subsection{H-SAF CDOP-2 phase}

On March 2012 H-SAF entered the five-year CDOP-2 phase, guided by the commitment to provide products and services in support of operational meteorology, hydrology, oceanography, climate and risk management, and to accomplish the following requirements:

1. Extend the limit of the long-term vision from 2015 up to the time of the new generation of EUMETSAT satellites - particularly, the geostationary (GEO) imaging and sounding Meteosat Third Generation (MTG) satellites and the low-Earth-orbiting (LEO) Post EUMETSAT Polar System (Post-EPS) satellites, platforms that will replace within a decade, respectively, the current GEO Meteosat Second Generation (MSG) satellites and the LEO Meteorological Operational (MetOp) satellites of the EUMETSAT Polar System (EPS) program - so as to concur in establishing their user requirements and potential operational products.

2. Support the future role of the combined numerical models (hydrological, meteorological and oceanographic) on estimation and forecast of precipitation, inland waters, sea circulation, climate monitoring, considering the added value of satellite-derived products in producing homogeneous maps of precipitation estimates over land and sea, ground soil moisture and snow water equivalent.

3. Exploit a wide range of current and future space missions for meteorology and altimetry (for ocean and inland water), such as the MTG and Post-EPS satellites, or the Sentinel satellites of the Global Monitoring for Environment and Security (GMES) program, which is a joint initiative of the European Commission (EC) and European Space Agency (ESA), and finally satellites and space missions being developed by extraEuropean agencies - especially, the Core Observatory of the Global Precipitation Measurement (GPM) mission (planned for launch in 2014), which is under joint development by the US National Aeronautics and Space Administration (NASA) and the Japan Aerospace Exploration Agency (JAXA).

4. Improve the provided service of online product validation, which would provide a level of confidence in the products in such a manner to allow their use by decision-making end users in risk management activities.
These activities are being carried out according to the following strategies and objectives:

- Concerning products:

- to continue providing operational high-quality products and services, enabling qualitative and quantitative exploitation by end users of the various precipitation, soil moisture, and snow products;

- to continuously improve product performance;

- to stepwise extend the coverage area, starting from specific areas of Africa up to delivering products for the full disk observed by MSG and, in the future, by MTG;

- to develop new products related to the enhanced technologies of upcoming space missions and satellite-borne sensors;

- to perform independent product validation;

- to assess the usefulness of products for water cycle issues - such as real-time flood risk management, landslides, avalanches and evaluation of water resources.

- Concerning services:

- to improve the HV program, which, although involving participation by eight countries for a total of twenty one test sites, leaves many uncovered areas in Europe; an extension is thus foreseen into the Iberian Peninsula, Great Britain, Scandinavia, the Balkans and, due to the envisaged coverage extension, also into Africa, along with the differentiation of hydrological models in order to improve the coverage of hydrological basin dimensions, geomorphological situations, and types of hydrological regimes;

- to consolidate specific PV services, comprised of online and off-line services: (1) online service is based on near real-time characterization of each product through the production of a quality index (derived from the completeness and quality of the input data used for each product generation) and a confidence index (derived from the combination of two statistical error parameters, the first of which is calculated off-line to establish a long product series, while the second is calculated online for the current product); and (2) off-line service is based on the evaluation of the product accuracy using multicategorical and continuous statistics;

- to consolidate and improve service activities, such as monitoring of service performances minimizing delays and preserving data integrity and harmonization of the H-SAF data service within the overall CDOP concept, also taking into account the EUMETSAT policy towards GMES; 
- to progressively extend user support services;

- to provide efficient user support and training, as well as effective communications with user communities via an ever improving website coupled with help-desk service.

- Concerning architecture:

- to upgrade the system architecture: the distributed architecture among product-generating participants will be consolidated, while CNMCA infrastructures will be upgraded both for product generation and central services, in order to be able to sustain disaster recovery procedures of distributed generation chains.

- Concerning cooperation:

- to progressively extend the user community: Table 2 shows a list of user communities that likely would be interested in H-SAF products;

- to provide support to other SAFs, especially those concerned with nowcasting, land processes, and climate monitoring;

- to achieve complete and concrete synergies with the other SAFs, as well as with the Central Facility, by implementing a combined production strategy for software development, maintenance, validation and operations;

- to intensify, in accordance with standing EUMETSAT policy, relationships with other SAFs, either through the mutual use of products or through the definition of specific federated activities;

- to establish and carry on operational cooperation with other space agencies involved in space missions of interest for H-SAF - particularly, with NASA and JAXA in conjunction with the GPM mission.

\subsection{H-SAF and international precipitation community}

Concerning the issue of international cooperation involving precipitation products, it is worth noting that $\mathrm{H}-\mathrm{SAF}$ is an active member of the International Precipitation Working Group (IPWG) (http://www.isac.cnr.it/ ipwg/), whose responsibilities include making available algorithms and datasets for operational and scientific use. The IPWG is a member of the Coordination Group for Meteorological Satellites (CGMS), an activity sponsored by the World Meteorological Organization (WMO). As a EUMETSAT contribution, the H-SAF algorithms are part of the IPWG inventory of satellite precipitation tools generating operational products. $\mathrm{H}-\mathrm{SAF}$ also participates in IPWG training activities that are aimed at enhancing the use of satellite precipitation products - especially in developing countries.

In addition, the international activity of H-SAF is conducted via the newly established EUMETSAT Precipitation Science Advisory Group (P-SAG). This group provides advice and support to EUMETSAT on satellite-based precipitation estimation in order to better coordinate all precipitationrelated activities carried out within the various SAFs. P-SAG is the first organization of its kind. Its creation testifies to the importance of precipitation in the context of EUMETSAT's service policy for the coming years. P-SAG membership consists of renowned scientists from throughout the world who cover all aspects of remote sensing, meteorology and hydrology, as well as representatives of EUMETSAT Headquarters. $\mathrm{H}-\mathrm{SAF}$, the SAF on Climate Monitoring (CM-SAF) and the SAF on Support to Nowcasting and Very Short Range Forecasting (NWC-SAF) are, in turn, being organized to form the EUMETSAT Joint Precipitation Working Group, which provides a link between the precipitation activities of the SAFs by exchanging algorithms and products, and establishing a common interface towards the P-SAG.

Finally, the utmost important project to which H-SAF has been called upon to participate in and contribute towards is the NASA-JAXA GPM mission (http://pmm.nasa.gov/ GPM). The GPM Core Observatory is planned for launch in 2014, hosting a new generation passive microwave radiometer, the GPM Microwave Imager (GMI), along with a Dualfrequency Precipitation Radar (DPR). The strategy is to calibrate the precipitation estimates of the entire constellation of operational passive microwave radiometers with GMI + DPR retrievals. H-SAF will provide its own algorithms and will be part of the international effort to ensure, to the degree possible, 3-hourly coverage of precipitation over the entire globe.

\section{H-SAF precipitation products}

Table 3 shows the complete list of precipitation products/algorithms for CDOP-2 and requires a somewhat detailed explanation. The first three columns identify each of the algorithms and associated products in three different ways, these being a unique identification (ID) code (column 1), a brief algorithm/product description with a version number (optional) included (column 2), and an underlying base name acronym (column 3 ). The ID code consists of the letter "H" (signifying H-SAF) followed by a number identifying a specific algorithm/product accounting for version number and/or significant upgrades - i.e., the ID code changes whenever there is an important change in the algorithm that is used to calculate its associated product. The base name acronym consists of the sequence PR-OBS- $n$, where "PR" indicates precipitation, "OBS" indicates observation (thus signifying that the associated precipitation products are based on satellite observations), while " $n$ " is a num- 
Table 2. User communities potentially addressed by H-SAF.

\begin{tabular}{|c|c|c|c|c|}
\hline Entity & Application & Precipitation & Soil moisture & Snow parameters \\
\hline \multirow[t]{4}{*}{$\begin{array}{l}\text { Operational } \\
\text { hydrological units }\end{array}$} & $\begin{array}{l}\text { Fluvial basin } \\
\text { management }\end{array}$ & $\begin{array}{l}\text { Early warning of potential } \\
\text { floods }\end{array}$ & $\begin{array}{l}\text { Landslides and runoff (forecast- } \\
\text { ing) }\end{array}$ & $\begin{array}{l}\text { Evaluation of flood damping or } \\
\text { enhancing factors }\end{array}$ \\
\hline & \multirow[t]{2}{*}{$\begin{array}{l}\text { Territory } \\
\text { management }\end{array}$} & $\begin{array}{l}\text { Extreme events statistics and } \\
\text { hydrological risk mapping. }\end{array}$ & \multirow{2}{*}{$\begin{array}{l}\text { Soil characterization } \\
\text { and hydrological } \\
\text { response units }\end{array}$} & \multirow{2}{*}{$\begin{array}{l}\text { Monitoring and exploitation } \\
\text { of snow and glaciers for river } \\
\text { regime regularization }\end{array}$} \\
\hline & & Public works planning. & & \\
\hline & $\begin{array}{l}\text { Water reservoir } \\
\text { evaluation }\end{array}$ & $\begin{array}{l}\text { Inventory of potential stored } \\
\text { water resources }\end{array}$ & $\begin{array}{l}\text { Monitoring of available water to } \\
\text { sustain vegetation }\end{array}$ & $\begin{array}{l}\text { Monitoring and exploitation of } \\
\text { snow and glaciers for drinkable } \\
\text { water and irrigation }\end{array}$ \\
\hline \multirow[t]{7}{*}{$\begin{array}{l}\text { National } \\
\text { meteorological } \\
\text { services }\end{array}$} & \multirow[t]{2}{*}{$\begin{array}{l}\text { Numerical weather } \\
\text { prediction }\end{array}$} & $\begin{array}{l}\text { Assimilation to represent latent } \\
\text { heat release inside the atmo- } \\
\text { sphere }\end{array}$ & \multirow{2}{*}{$\begin{array}{l}\text { Input of latent heat by } \\
\text { evapotranspiration } \\
\text { through the planetary } \\
\text { boundary layer }\end{array}$} & \multirow[t]{2}{*}{$\begin{array}{l}\text { Input of radiative heat } \\
\text { from surface to } \\
\text { atmosphere }\end{array}$} \\
\hline & & Evaluation of NWP model skill. & & \\
\hline & \multirow[t]{3}{*}{ Nowcasting } & $\begin{array}{l}\text { Public information on actual } \\
\text { weather }\end{array}$ & \multirow{3}{*}{$\begin{array}{l}\text { Warning on the status } \\
\text { of the territory for } \\
\text { transport in } \\
\text { emergencies }\end{array}$} & Warning of avalanches \\
\hline & & $\begin{array}{l}\text { Warning for fishery and coastal } \\
\text { zone activities }\end{array}$ & & Tourism information \\
\hline & & $\begin{array}{l}\text { Warning for agricultural works } \\
\text { and crop protection }\end{array}$ & & $\begin{array}{l}\text { Assistance to aviation during } \\
\text { takeoff and landing }\end{array}$ \\
\hline & \multirow{2}{*}{ Climate monitoring } & \multirow{2}{*}{$\begin{array}{l}\text { Representation of the } \\
\text { global water cycle in } \\
\text { general circulation models }\end{array}$} & \multirow{2}{*}{$\begin{array}{l}\text { Monitoring of } \\
\text { desertification } \\
\text { processes }\end{array}$} & Monitoring glacier extension \\
\hline & & & & $\begin{array}{l}\text { Monitoring changes of plane- } \\
\text { tary albedo }\end{array}$ \\
\hline $\begin{array}{l}\text { Operational } \\
\text { oceanography }\end{array}$ & $\begin{array}{l}\text { Numerical ocean } \\
\text { circulation mod- } \\
\text { els }\end{array}$ & $\begin{array}{l}\text { Assimilation of fresh water in- } \\
\text { put to represent density, salin- } \\
\text { ity and heat release inside the } \\
\text { ocean }\end{array}$ & & \\
\hline $\begin{array}{l}\text { Operational } \\
\text { climatology }\end{array}$ & $\begin{array}{l}\text { Numerical } \\
\text { atmosphere- } \\
\text { ocean coupled } \\
\text { models }\end{array}$ & $\begin{array}{l}\text { Assimilation of fresh water in- } \\
\text { put to represent density, salin- } \\
\text { ity and heat release inside the } \\
\text { ocean }\end{array}$ & & \\
\hline \multirow[t]{5}{*}{ Civil protection } & \multirow[t]{2}{*}{$\begin{array}{l}\text { Preparation for } \\
\text { emergencies }\end{array}$} & $\begin{array}{l}\text { Progressive level of attention } \\
\text { function of rainfall monitoring }\end{array}$ & $\begin{array}{l}\text { Monitoring soil moisture } \\
\text { growth }\end{array}$ & Monitoring snow accumulation \\
\hline & & $\begin{array}{l}\text { Preparation of facilities and } \\
\text { staff for a possible emergency }\end{array}$ & $\begin{array}{l}\text { Planning of in-field activities } \\
\text { for event mitigation }\end{array}$ & $\begin{array}{l}\text { Planning of in-field activities } \\
\text { for event mitigation }\end{array}$ \\
\hline & $\begin{array}{l}\text { Emergency man- } \\
\text { agement }\end{array}$ & Alert to population & $\begin{array}{l}\text { Operational conditions for } \\
\text { transport and use of staff and } \\
\text { mitigation facilities }\end{array}$ & $\begin{array}{l}\text { Operational conditions for } \\
\text { transport and use of staff and } \\
\text { mitigation facilities }\end{array}$ \\
\hline & \multirow[t]{2}{*}{$\begin{array}{l}\text { Post-emergency } \\
\text { phase }\end{array}$} & \multirow{2}{*}{$\begin{array}{l}\text { Deranking of alert level } \\
\text { and monitoring of } \\
\text { event cessation. }\end{array}$} & $\begin{array}{l}\text { Withdrawing of staff and miti- } \\
\text { gation facilities }\end{array}$ & $\begin{array}{l}\text { Withdrawing of staff and miti- } \\
\text { gation facilities }\end{array}$ \\
\hline & & & $\begin{array}{l}\text { Assessment of vulnerability to } \\
\text { possible event iteration }\end{array}$ & $\begin{array}{l}\text { Assessment of vulnerability to } \\
\text { possible event iteration }\end{array}$ \\
\hline \multirow{7}{*}{$\begin{array}{l}\text { Research \& } \\
\text { development } \\
\text { activities }\end{array}$} & \multirow[t]{2}{*}{ Meteorology } & $\begin{array}{l}\text { Improved knowledge of the pre- } \\
\text { cipitation process }\end{array}$ & \multirow{2}{*}{$\begin{array}{l}\text { Assessment of the role of } \\
\text { observed soil moisture in } \\
\text { NWP, either for verification } \\
\text { or initialization }\end{array}$} & \multirow{2}{*}{$\begin{array}{l}\text { Assessment of the role of } \\
\text { observed snow parameters } \\
\text { in NWP, either for } \\
\text { verification or initialization }\end{array}$} \\
\hline & & $\begin{array}{l}\text { Assimilation of precipitation } \\
\text { observation in NWP models }\end{array}$ & & \\
\hline & \multirow[t]{3}{*}{ Hydrology } & $\begin{array}{l}\text { Downscaling/upscaling of satel- } \\
\text { lite precipitation observations }\end{array}$ & $\begin{array}{l}\text { Downscaling/upscaling of satel- } \\
\text { lite soil moisture observations }\end{array}$ & $\begin{array}{l}\text { Downscaling/upscaling of satel- } \\
\text { lite snow observations }\end{array}$ \\
\hline & & $\begin{array}{l}\text { Fusion with ground-based ob- } \\
\text { servations }\end{array}$ & $\begin{array}{l}\text { GIS-based fusion with ground- } \\
\text { based observations }\end{array}$ & $\begin{array}{l}\text { GIS-based fusion with ground- } \\
\text { based observations }\end{array}$ \\
\hline & & Assimilation and impact studies & Assimilation and impact studies & Assimilation and impact studies \\
\hline & Civil protection & $\begin{array}{l}\text { Decisional models for the alert } \\
\text { system }\end{array}$ & $\begin{array}{l}\text { Organizational models for oper- } \\
\text { ating over moist soil }\end{array}$ & $\begin{array}{l}\text { Organizational models for oper- } \\
\text { ating over snow }\end{array}$ \\
\hline & $\begin{array}{l}\text { Oceanographic } \\
\text { units }\end{array}$ & $\begin{array}{l}\text { Evaluation as part of the global } \\
\text { water cycle }\end{array}$ & & \\
\hline
\end{tabular}


Table 3. H-SAF precipitation algorithms/products developed for or under development for CDOP-1 and CDOP-2 (see text for details). (Products developed during DP and CDOP-1 phases for H-SAF area are indicated with *.)

\begin{tabular}{|c|c|c|c|c|}
\hline ID Code & Algorithm/product description & Base name acronym & Timeliness & Spatial coverage \\
\hline H01* & $\begin{array}{l}\text { Precipitation rate at ground from microwave } \\
\text { (MW) conically scanning radiometers (SSMIS) } \\
\text { using a Bayesian (CDRD) algorithm (with } \\
\text { phase flag) - Version } 1\end{array}$ & PR-OBS-1 & $2.5 \mathrm{~h}$ & $\mathrm{H}-\mathrm{SAF}$ area/MSG full disk \\
\hline $\mathrm{H} 02^{*}$ & $\begin{array}{l}\text { Precipitation rate at ground from MW cross- } \\
\text { track scanning radiometers (AMSU-A + MHS) } \\
\text { using a neural network (PNPR) algorithm (with } \\
\text { phase flag) - Versions } 1 / 2\end{array}$ & PR-OBS-2 & $30 \mathrm{~min} / 2.5 \mathrm{~h}$ & $\mathrm{H}-\mathrm{SAF}$ area/MSG full disk \\
\hline H03* & $\begin{array}{l}\text { Precipitation rate at ground from the blended } \\
\text { GEO/IR-LEO/MW rapid-update technique } \\
\text { (NRLT) }\end{array}$ & PR-OBS-3 & $15 \mathrm{~min} / 25 \mathrm{~min}$ & $\mathrm{H}-\mathrm{SAF}$ area/MSG full disk \\
\hline H04* & $\begin{array}{l}\text { Precipitation rate at ground by LEO/MW sup- } \\
\text { ported by GEO/IR (with phase flag): advection } \\
\text { of MW rain fields is merged with a morphing } \\
\text { technique based on a forward-backward com- } \\
\text { putational scheme }\end{array}$ & PR-OBS-4 & $4 \mathrm{~h} / 5 \mathrm{~h}$ & H-SAF area/MSG full disk \\
\hline H05* & $\begin{array}{l}\text { Accumulated precipitation at ground from } \\
\text { blended LEO/MW + GEO/IR supported by } \\
\text { precipitation analysis (NWP first guess + rain } \\
\text { gauges) and adaptive statistical correction }\end{array}$ & PR-OBS-5 & $15 \mathrm{~min} / 25 \mathrm{~min}$ & $\mathrm{H}-\mathrm{SAF}$ area/MSG full disk \\
\hline H15* & $\begin{array}{l}\text { Convective precipitation rate at ground from } \\
\text { blending of LEO/MW precipitation rates and } \\
\text { GEO/IR brightness temperatures after a pre- } \\
\text { screening using NEFODINA convective mask }\end{array}$ & PR-OBS-6 & $15 \mathrm{~min} / 25 \mathrm{~min}$ & $\mathrm{H}-\mathrm{SAF}$ area/MSG full disk \\
\hline H17 & $\begin{array}{l}\text { Precipitation rate at ground from MW coni- } \\
\text { cally scanning radiometers (SSMIS) using a } \\
\text { Bayesian (CDRD) algorithm (with phase flag) } \\
\text { - Version } 2\end{array}$ & PR-OBS-1 & $2.5 \mathrm{~h}$ & MSG full disk \\
\hline H18 & $\begin{array}{l}\text { Precipitation rate at ground from MW cross- } \\
\text { track scanning radiometers (AMSU-A + MHS) } \\
\text { using a neural network (PNPR) algorithm (with } \\
\text { phase flag) - Version } 3\end{array}$ & PR-OBS-2 & $2.5 \mathrm{~h}$ & MSG full disk \\
\hline H19 & $\begin{array}{l}\text { Precipitation rate at ground from GPM Core } \\
\text { Satellite GMI measurements (with DPR sup- } \\
\text { port) using a Bayesian (CDRD) algorithm (with } \\
\text { phase flag) }\end{array}$ & PR-OBS-7 & NA & MSG full disk (except for polar zones) \\
\hline $\mathrm{H} 20$ & $\begin{array}{l}\text { Precipitation rate at ground from GPM Core } \\
\text { Satellite GMI measurements (with DPR sup- } \\
\text { port) using a neural network (PNPR) algorithm } \\
\text { (with phase flag) }\end{array}$ & PR-OBS-8 & NA & MSG full disk (except for polar zones) \\
\hline $\mathrm{H} 21$ & $\begin{array}{l}\text { High frequency MW delineation of cloud areas } \\
\text { having a possible new development of hydrom- } \\
\text { eteors: detection is carried out by combining } \\
\text { different MHS channels }\end{array}$ & PR-OBS-9 & $2.5 \mathrm{~h}$ & MSG full disk \\
\hline $\mathrm{H} 22$ & $\begin{array}{l}\text { Snowfall intensity calculated by a dedicated } \\
\text { module of the } 183 \text {-WSL method using a com- } \\
\text { bination of MHS channels }\end{array}$ & PR-OBS-10 & $2.5 \mathrm{~h}$ & MSG full disk \\
\hline $\mathrm{H} 40$ & $\begin{array}{l}\text { Precipitation rate at ground from the blended } \\
\text { GEO/IR-LEO/MW rapid-update technique } \\
\text { (NRLT) }\end{array}$ & PR-OBS-3-FCI & $15 \mathrm{~min} / 25 \mathrm{~min}$ & H-SAF area/MTG full disk \\
\hline H41 & $\begin{array}{l}\text { Precipitation rate at ground by LEO/MW sup- } \\
\text { ported by GEO/IR (with phase flag): advection } \\
\text { of MW rain fields is merged with a morphing } \\
\text { technique based on a forward-backward com- } \\
\text { putational scheme }\end{array}$ & PR-OBS-4-FCI & $4 \mathrm{~h} / 5 \mathrm{~h}$ & H-SAF area/MTG full disk \\
\hline $\mathrm{H} 42$ & $\begin{array}{l}\text { Accumulated precipitation at ground from } \\
\text { blended LEO/MW + GEO/IR supported by } \\
\text { precipitation analysis (NWP first guess + rain } \\
\text { gauges) and adaptive statistical correction }\end{array}$ & PR-OBS-5-FCI & $15 \mathrm{~min} / 25 \mathrm{~min}$ & $\mathrm{H}$-SAF area/MTG full disk \\
\hline H50 & $\begin{array}{l}\text { Convective precipitation rate at ground by using } \\
\text { lightning rate occurrences from LI supported by } \\
\text { GEO/IR and rainfall patterns }\end{array}$ & PR-OBS-11-LI & $15 \mathrm{~min}$ & Europe \\
\hline
\end{tabular}


ber designating a particular algorithm methodology, regardless of its associated algorithm/product version. In addition, a base name acronym may terminate with the letter sequences "FCI" or "LI", indicating that a future product will be making use of measurements from the Flexible Combined Imager (FCI) or Lightning Imager (LI) instruments scheduled for flight on future MTG satellites. Note that the table is organized according to increasing ID code.

The next two columns in Table 3 provide the so-called timeliness (column 4), a vital user parameter which is defined as the time interval between a level 1 observation and its associated product availability at the user site (assuming a means of data dissemination has been defined), and the spatial coverage domain for each product (column 5). Note that there are two main options for the spatial coverage, these being the nominal $\mathrm{H}-\mathrm{SAF}$ area $\left(25^{\circ} \mathrm{N}-75^{\circ} \mathrm{N}\right.$ latitude, $25^{\circ} \mathrm{W}-45^{\circ} \mathrm{E}$ longitude) and a wider area covering the full disk observed by the Spinning Enhanced Visible and InfraRed Imager (SEVIRI) instrument onboard GEO MSG satellites. (Note, however, that products making use of MSG data extend to $65^{\circ}$ latitude/longitude only because of parallax issues.) Also note that several products show both options. This is because these products are first generated for the $\mathrm{H}$ SAF area and then extended to the MSG full disk area following an evolution of the corresponding algorithms, and/or because there are important differences in the timeliness associated with each area - as indicated in corresponding rows of column 4.

Six different precipitation products have been developed during the DP and CDOP-1 phases; these are marked with an asterisk in column 1 of Table 3 and refer to the H-SAF area only. Two of these products are based on passive microwave (PMW) measurements taken from radiometers onboard different sun-synchronous near-polar-orbiting LEO satellites ${ }^{1}$ : PR-OBS-1, which is developed by CNR-ISAC, utilizes the Special Sensor Microwave Imager/Sounder (SSMIS) conically scanning radiometers flown onboard satellites of the US Defense Meteorological Satellite Program (DMSP) (note that PR-OBS-1 was originally conceived to utilize the Special Sensor Microwave Imager (SSM/I) on an earlier generation of DMSP satellites, now no longer available), while PR-OBS-2, which is also developed by CNR-ISAC, utilizes the coupled Advanced Microwave Sounding Unit A (AMSU-A) and Microwave Humidity Sounder (MHS) cross-track scanning radiometers that are flown onboard the US National Oceanic and Atmospheric Administration (NOAA) Polar-orbiting Operational Environmental Satellites (POES), referred to as NOAA-18 and NOAA-19, as well as on EUMETSAT's two Meteorological Operational satellites MetOp-A/B. Then, there are the three combined

\footnotetext{
${ }^{1}$ For exhaustive and detailed information on all past, present and planned Earth observation satellites and instruments, see the Observing Systems Capability Analysis and Review Tool (OSCAR) web page developed by WMO - http://www.wmo-sat.info/oscar/.
}

infrared/microwave (IR-MW) precipitation products, PROBS-3 and PR-OBS-4 (both developed by CNR-ISAC) and PR-OBS-6 (developed by CNMCA), which utilize infrared (IR) measurements taken by the MSG SEVIRI in combination with previous PMW-only precipitation estimates. Finally, there is an accumulation-based product, PR-OBS-5 (also developed by CNMCA), which accumulates precipitation on the SEVIRI grid presently obtained from PR-OBS-3 (but in the future this will also be done in conjunction with PR-OBS-4).

During CDOP-2 all six algorithms and products will be upgraded and extended to cover the MSG full disk area. Moreover, several important changes are foreseen for some algorithms. Thus, $\mathrm{H} 17$ and $\mathrm{H} 18$ will replace $\mathrm{H} 01$ and $\mathrm{H} 02$ for PR-OBS-1 and PR-OBS-2, respectively. In addition, other new products will be generated during CDOP-2 - especially, products for the future MTG satellites and the Core Observatory of the GPM mission. For example, H40, H41 and H42, which will be based on the FCI instrument onboard MTG (replacing and extending the SEVIRI radiometer onboard MSG), will replace H03, H04 and H05 for PR-OBS-3, PR-OBS-4 and PR-OBS-5, respectively, while PR-OBS-11 will be developed by CNMCA for the LI instrument onboard MTG, and PR-OBS-7 and PR-OBS- 8 will be developed by CNR-ISAC for GPM's GMI radiometer with the GPM DPR radar providing supporting information. Finally, two new products (PR-OBS-21 and PR-OBS-22), which make use of high frequency MW channels on the MHS radiometers, are presently under development by CNR-ISAC.

Finally, each product will be supplied with a pixel-based quality flag, which will offer to the end users an effective criterion for evaluating the products and assist in their apposite selection and application for a given analyzed situation or scenario. Specifically, for each precipitation product, the quality flag is evaluated so as to take into account particular aspects of the associated algorithm, as well as characteristics of the input data (satellite data or other precipitation products), and of the observed event - all of which influence the overall reliability of the precipitation product itself.

\subsection{PR-OBS-1}

PR-OBS-1 is based on a physically based Bayesian PMW precipitation retrieval algorithm that has been developed according to a new methodology called Cloud Dynamics and Radiation Database (CDRD), an evolution of the more traditional Cloud Radiation Database (CRD) methodology see Sanò et al. (2013), Casella et al. (2013) and Smith et al. (2013) for a thorough presentation of the CDRD methodology and algorithm, and also Mugnai et al. (2013) for a historical overview of the CRD and CDRD methodologies and applications. The main objective in transforming from CRD to CDRD has been to reduce non-uniqueness problems affecting retrieval solutions (Panegrossi et al., 1998) by selecting, for any given observational situation, 
microphysical profiles from the database, which constitutes the a priori knowledge for the Bayesian solver, that are optimally consistent with environmental conditions. This is achieved by using dynamical-thermodynamical-hydrological (DTH) parameter constraints in addition to multispectral PMW brightness temperatures (TBs) measured by available satellite-borne radiometers - see Sanò et al. (2013) for a description of the CDRD algorithm and Smith et al. (2013) for a detailed analysis of the selection of an optimal set of DTH parameters.

The CDRD algorithm developed for PR-OBS-1 makes use of a large database of simulated precipitating cloud structures, associated DTH variables and associated top-ofatmosphere satellite-view TBs that have been generated by first simulating 60 different precipitating events over the European/Mediterranean Basin region by means of the cloud resolving model (CRM) Non-hydrostatic Modeling System (NMS) of Tripoli (1992) and Tripoli and Smith (2013a,b). The simulation outputs (that is the vertical profiles of meteorological-microphysical variables) have been then processed by an advanced radiative transfer model (RTM) to produce associated modeled TBs as counterparts to observed TBs (see Casella et al., 2013). The CDRD algorithm has been tested and verified, with improved results as compared to a corresponding CRD algorithm. This was accomplished by focusing in a very detailed fashion on several precipitation case studies involving a mix of highly variable convective and stratiform rain situations over Italy's Lazio region that were observed both by SSM/I and SSMIS radiometers and by the polarimetric Polar 55C Doppler C-band radar system operated at CNR-ISAC in Rome, a precision radar system which was used as the verification standard (see Sanò et al., 2013). The verification results were excellent. In addition, retrievals from the CDRD algorithm for one-year of TRMM Microwave Imager (TMI) observations taken over the southern Mediterranean region (TRMM refers to the NASA-JAXA Tropical Rainfall Measuring Mission and the associated satellite observatory) have been compared against corresponding retrievals from TRMM's official TMI algorithm using the TRMM Precipitation Radar (PR) as the comparison reference standard. Whereas the over ocean retrievals were nearly equivalent (with the CDRD algorithm indicating slightly better comparison statistics), the over land CDRD results indicate significant improvement with respect to the official TMI algorithm (see Mugnai et al., 2013).

The CDRD algorithm has been designed for applications with a variety of conically scanning MW radiometers flying on current and future satellites. However, in its present version for PR-OBS-1, it is applied to SSMIS radiometer observations only (with the necessary accompanying DTH observations obtained from analysis and forecast data produced by ECMWF's operational forecast model). The algorithm is operational and provides instantaneous surface precipitation rate (as well as an indication of precipitation phase) at $13.2 \times 15.5 \mathrm{~km}^{2}$ horizontal resolution, consistent with the SSMIS high-frequency window channel resolution. The observing cycle of the PR-OBS-1 product depends on the SSMIS swath width $(\sim 1700 \mathrm{~km})$, and on the number and equatorial crossing times (ECTs) of available DMSP satellites. In general, each point on the earth's surface is observed twice per day by each satellite (i.e., once in descending mode and once, about half a day later, in ascending mode). However, coverage density increases with latitude, and whereas at low latitudes there are gaps between the swaths of successive orbits, at high latitudes there are more than two observations per day because of partial overlap of successive swaths. At present, there are three DMSP satellites flying SSMIS radiometers: DMSP F16, DMSP F17 and DMSP F18 having descending ECTs at approximately 05:30, 05:50 and 08:10 mean local solar time (LST), respectively. (Note that whereas the ECTs remain nearly constant throughout a given year, orbit drift will cause slow changes over time - see, e.g., http://www.ssmi.com/support/crossing_times.html.) Thus, it can be assumed that on a given day the entire H-SAF area is currently observed by available SSMIS radiometers at least three times in the early morning and three more times in the late afternoon. By the same token, since the radiometer scan swaths extend over more and more time zones as latitude increases in either hemisphere, the actual local times at which a given location on the earth's surface is observed by a given radiometer may change considerably (even hours). As a consequence, the actual interval between successive observations may also change considerably (say, from about $1 / 2 \mathrm{~h}$ to a few hours) for both the morning and afternoon observations, depending on latitude and the concomitant swath overlap factor. An example of a PR-OBS-1 product, as a portion of Fig. 2, is shown and discussed within the next subsection.

Within the DP and CDOP- 1 phases, the PR-OBS-01 product corresponding to the CDRD methodology is referred to as H01. This product is now operational over the H-SAF area and will be soon extended to the MSG full disk. In addition, during CDOP-2 the CDRD methodology will continuously evolve with a new product (H17) foreseen for early 2014 with extensions to the MSG full disk. Finally, a new product (H19) will be developed, within the GPM/H-SAF partnership, for the GPM Core Observatory's GMI radiometer using the same CDRD methodology, but also taking advantage of distinct and correlated $\mathrm{Ka} / \mathrm{Ku}$-band radar information provided by the new GPM DPR radar.

\subsection{PR-OBS-2}

The algorithm used for the current operational version of PR-OBS-2 was originally inspired by the artificial neural network (ANN) approach of Surussavadee and Staelin (2008a,b), who developed an ANN-based precipitation retrieval algorithm for applications with measurements from AMSU-A + MHS (or + AMSU-B, i.e., MHS's ancestor instrument on an earlier generation of NOAAPOES satellites), trained through a database generated from 
CRM simulations of several precipitation events around the globe carried out by means of the Pennsylvania State University/National Center for Atmospheric Research (PSU/NCAR) Mesoscale Model 5 (MM5) described by Dudhia (1993) and Grell et al. (1994).

Within H-SAF, this new ANN algorithm has been modified and optimized for the European/Mediterranean Basin area. It is referred to as the Passive-microwave Neuralnetwork Precipitation Retrieval (PNPR) algorithm (see Mugnai et al., 2013), being based on a newly developed optimal three-layer ANN trained using the same 60 NMS simulations and the same RTM code used for the CDRD algorithm of PR-OBS-1. This choice has been motivated by the H-SAF requirement for seeking consistency between the PR-OBS-1 and PR-OBS-2 products when the algorithms are applied to close-in-time measurements acquired by conically and crosstrack scanning radiometers for the same rainfall event. That is the reason why the training database for the PNPR algorithm is based on the same physical foundation used for the CDRD algorithm. Moreover, the two algorithms use the same procedures to determine the phase of the retrieved precipitation (following the studies of Grody et al., 2000; Rosenkranz, 2003; and Surussavadee and Staelin, 2009), as well as the same precipitation screening methodology following an algorithm developed by Chen and Staelin (2003), and finally the same specially tailored surface identification procedures (see Mugnai et al., 2013).

The simulated satellite TB vectors are consistent with the AMSU-A and MHS channel frequencies and have instantaneous fields of view (IFOVs) at the ground that depend on the view angle along the scan. In order to produce unique relationships between the TB vectors for the individual viewing angles and the associated surface precipitation rates, a variable sensor resolution, defined according to the nominal MHS resolution (varying from $16 \times 16 \mathrm{~km}^{2}$ circular at nadir to $26 \times 52 \mathrm{~km}^{2} / \mathrm{oval}$ at scan edge), has been chosen as the PR-OBS-2 product spatial resolution. As input data, the algorithm incorporates TBs measured by the AMSU-A and MHS radiometers: three AMSU-A channels $(50.3 \pm 0.50,52.8 \pm 0.105,53.596 \pm 0.115 \mathrm{GHz})$, all five MHS channels $(89 \pm 0.9,150 \pm 0.9,183.31 \pm 1,183.31 \pm 3$, $183.31 \pm 7 \mathrm{GHz}$ ) and various additional channel-derived variables. In addition, several geophysical/geographical parameters (i.e., latitude, terrain height, surface type, season) are used as input data to guide the PNPR algorithm towards selecting values of the ANN coefficients that are most representative of an observed scene. The pixel number along the scan is an additional input parameter used by the ANN for reducing, according to Goldberg et al. (2001), limb smearing produced by the changing atmospheric path length along the scan. The algorithm uses a unique ANN that retrieves the surface precipitation rate for all types of surface backgrounds represented in its database, i.e., land, ocean, ice, snow or coast.
Analogous to PR-OBS-1, the observing cycle of the PROBS-2 product depends on the swath widths of AMSU-A and MHS ( $\sim 2050 \mathrm{~km}$ and $\sim 2150 \mathrm{~km}$, respectively), as well as on the number and ECTs of the satellites containing this instrumental suite. Currently, there are four such satellites NOAA-18 and NOAA-19, both having descending ECTs at about 01:30 LST, and MetOp-A and MetOp-B, both having descending ECTs at about 09:30 LST. (As for DMSP satellites, orbit drift can cause slow changes in the ECTs over time.) Thus, on a given day, the entire H-SAF area is observed by the AMSU-A + MHS radiometer pairs at a minimum of eight distinct times (i.e., twice before 01:30 LST, twice before 09:30 LST, twice after 13:30 LST and twice after 21:30 LST), while surrounding each nominal time event there may other time events because of overlapping swaths as latitude increases. And again, as for the SSMIS observations, because of the wide swaths the actual local times at which a given location on the earth surface is observed by the various AMSU-A and MHS radiometers may change considerably (even hours).

The PR-OBS-2 product is operational and consists of the surface precipitation rate with an indication of phase. Whereas the original PR-OBS-2 product (H02) used the Surussavadee and Staelin (2008a,b) methodology and was applied to the H-SAF area only, the new PNPR algorithm being used for PR-OBS- 2 uses the independently developed ANN for CDOP-2 and will be soon extended to the MSG full disk. This algorithm will eventually evolve into $\mathrm{H} 18$ by 2014 . In addition, a new product (H20) will be developed for GPM's GMI, perhaps adopting an even more refined ANN procedure, but one maintaining consistency with the corresponding GPM Bayesian CDRD product (H19).

Figure 2 shows a comparison between the PR-OBS- 1 and PR-OBS-2 maps of surface precipitation rate for two closein-time SSMIS and AMSU-A + MHS observations of an intense precipitation event that caused extensive flooding and damage along the northern Tyrrhenian coasts of Italy on 25 October 2011. Similar to the findings of Mugnai et al. (2013) for a different case study, there is close correspondence in rain rates for the heavy precipitation areas (in spite of a 21 min difference between the two observations), noting that differences are more evident for the light precipitation areas over the North Sea.

\subsection{PR-OBS-3}

PR-OBS-3 provides an instantaneous rain intensity product (H03) at the temporal $(15 \mathrm{~min})$ and spatial $(\sim 8 \mathrm{~km}$ over the H-SAF area) resolution of the MSG SEVIRI, using the blended-satellite rapid-update technique originally developed at the US Naval Research Laboratory (NRL) - and therefore referred to as NRL Technique (NRLT) - which is based on a real-time, underlying collection of time and space matching of IR TBs at $10.8 \mu \mathrm{m}$ from GEO satellites and rain intensity estimations from PMW satellite sensors (Turk et 

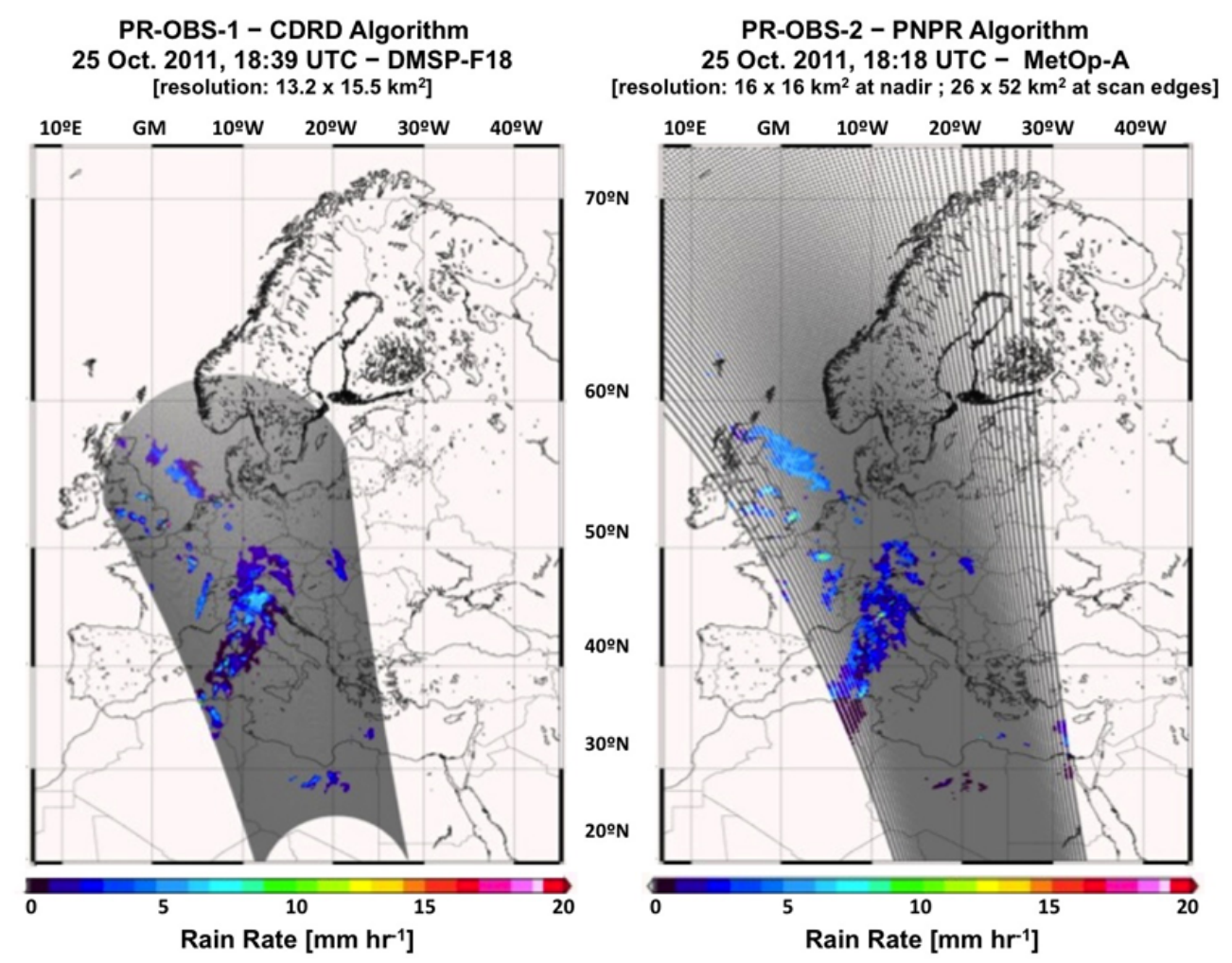

Fig. 2. Example of PR-OBS-1 and PR-OBS-2 precipitation rate retrievals on 25 October 2011. The left panel shows H01 product relative to a SSMIS (DMSP F18) overpass at 18:39 UTC, while the right panel shows near-correlated H02 product relative to an AMSU-A + MHS (MetOp-A) overpass at 18:18 UTC.

al., 2000; Turk and Miller, 2005; Torricella et al., 2007). The NRLT processing is triggered as soon as a new slot of SEVIRI data at $10.8 \mu \mathrm{m}$ is available. As a second step, the identification of the PMW measurements coincident in time and space with the TBs at $10.8 \mu \mathrm{m}$ of the currently processed SEVIRI image is performed. The coincident data are subsequently located in a geographical latitude/longitude grid, and for each grid box the histogram of the IR TBs and that of the corresponding PMW rain rates are built and then combined by means of a probabilistic histogram matching technique (Calheiros and Zawadzki, 1987) to produce geolocated TB vs. PMW rain-rate relationships. These relationships are then used to assign a rainfall intensity value to each SEVIRI pixel.

As soon as a grid box is refreshed with new data, the corresponding relationship is renewed using updated IR TB and PMW rain-rate histograms. Relationships older than $24 \mathrm{~h}$ with respect to the acquisition time of the IR TB are considered unreliable and consequently no rainfall intensity values are assigned until a refresh of the relationship is done. The key point of this technique is thus to provide instantaneous rainfall estimations at the GEO spatial and temporal scales, which are consistent with the nature and development of the precipitating cloud systems, by overcoming the scarcity of PMW overpasses with the more frequent GEO slots and the weak connection between the rain intensity and IR TBs with the calibration of the IR TBs by the PMW rain rates. Figure 3 shows an example of PR-OBS-03 relative to 25 October 2011 at 00:12 UTC - i.e., for the same event shown in Fig. 2. Notably, the precipitation rate map is given at a time when no MW radiometer overpasses were available.

Recently, the $\mathrm{H} 03$ product entered the CDOP- 2 phase in the pre-operational stage with the NRLT fed by the H02 product. In the near future, the processing chain of PROBS-3 will be improved by activating new software modules for merging the $\mathrm{H} 01$ and $\mathrm{H} 02$ input data and implementing a preventive classification of cloudy pixels into precipitating and non-precipitating. These lines of development tackle the two main drawbacks of PMW-IR blended techniques: (1) the lack of a regular and possibly uninterrupted flux of PMW precipitation products, which has implications on the continuous updating of the IR TB vs. PMW rain-rate relationships; and (2) the erroneous precipitation assignments to cold thin clouds such as cirrus, due to the fact that the blended techniques assume the colder the cloud top, the higher the associated precipitation intensity value. The synergistic use of H01 and H02, taking into account their different resolutions, error structures and other characteristics, will assure a higher number of suitable PMW passages than the present situation. The cloud classification issue will be tackled with 
EUMETSAT H-SAF PR-OBS-3 Instantaneous Rain Rate retrieved from IR-MW blending data

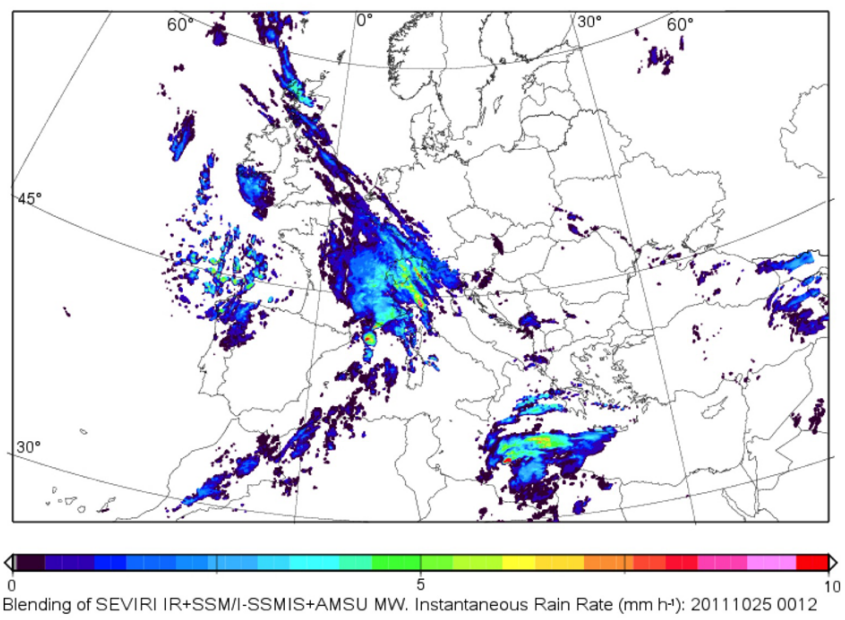

Fig. 3. Example of PR-OBS-3 precipitation rate on 25 October 2011 at 00:12 UTC.

a twofold approach. First, the cloud classification products from the NWC-SAF (e.g., cloud type) and from CNMCA (e.g., NEFODINA, which is described in Sect. 3.6) will be exploited to distinguish convective and non-convective, precipitating and non-precipitating, and cirrus clouds (these latter to be removed). Second, the SEVIRI spectral channels sensitive to microphysical properties at the cloud top will be exploited in combination with a scattering index derived from the quasi-window channels of the $183 \mathrm{GHz}$ band of MHS to build up a "precipitation mask".

In addition, during CDOP-2 the geographical region of PR-OBS-3 production will be enlarged to include the MSG full disk area. Moreover, the algorithm will be expanded for the ingestion of the MTG FCI data (product H40 in Table 3).

\subsection{PR-OBS-4}

PR-OBS-04 is based on the precipitation rate merging technique called CMORPH (CPC MORPHing technique), which has been developed at NOAA Climate Prediction Center (CPC) (see Joyce et al., 2004). CMORPH fills up the discontinuity in the PMW rain maps that is due to the (often large) time gaps between successive LEO satellite overpasses, by generating synthetic PMW rain fields at any time between two successive PMW observations using their PMW rain estimates and the advection vectors, calculated with GEO IR data, that connect these estimates in space and time. Specifically, this technique, which may yield precipitation fields that are almost continuous both spatially and temporally, consists in a forward-backward procedure in which the shape and intensity of the PMW rain field at the time of any LEO satellite overpass is forward propagated, using GEO IR motion vectors, up to the PMW rain field of the successive LEO satellite overpass, while this latter rain field is backward propagated to the first one. Then, the two resulting partial rain fields are "morphed" (i.e., time-weighted via a linear interpolation method) so as to generate a synthetic PMW rain field at any time within the two PMW observations.

Within H-SAF the CMORPH method has been customized with the official rain-rate fields from PR-OBS-1 and PROBS-2, which are combined to produce a merged rain field rescaled on a pre-assigned grid having $8 \mathrm{~km}$ spatial resolution and with a $30 \mathrm{~min}$ sampling time. Then, propagation vector matrices, which are produced by computing spatial lag correlations over successive images of the MSG $10.8 \mu \mathrm{m}$ channel, are used to propagate these rain maps in time and space as described above (note that all rain fields within each $2.5^{\circ}$ latitude/longitude box are propagated in the same direction).

At present, PR-OBS-4 is in the pre-operational stage and it is not generated on a regular basis. A prototype example of CMORPH in the H-SAF operational scheme using the 183WSL rain retrieval method of Laviola and Levizzani (2008, 2009, 2011) is provided in Fig. 4.

In the framework of H-SAF, the PR-OBS-04 algorithm runs in a dedicated operational chain producing one morphed rain map every $3-4 \mathrm{~h}$. The exact time rate for the morphing product will be fixed once all testing stages are completed. During CDOP-2, PR-OBS-4 will be extended to the MSG full disk and successively will be modified to ingest the GEO satellite data from the FCI instrument onboard MTG (product $\mathrm{H} 41$ in Table 3).

\subsection{PR-OBS-5}

PR-OBS-5 provides an accumulated precipitation product at ground (H05), which is based on a procedure that uses as input the precipitation intensities generated by PR-OBS-3 (and soon by PR-OBS-4) over the H-SAF area. The product is generated for each SEVIRI pixel, which has an IFOV of about $8 \mathrm{~km}$ in the H-SAF area. However, 3-4 SEVIRI neighboring pixels are convoluted in such a way that the actual PR-OBS-5 spatial resolution is $30 \mathrm{~km}$. Nevertheless, the sampling is still made at $\sim 5 \mathrm{~km}$ intervals, roughly consistent with the SEVIRI pixel grid over Europe. The product is generated every $3 \mathrm{~h}$, and provides the accumulated precipitation over $3,6,12$, and $24 \mathrm{~h}$ prior to the reference time (i.e., nominal time). Based on the H-SAF requirements, every $3 \mathrm{~h}$ the $\mathrm{H} 05$ product is processed over the entire H-SAF area within 15 min following the delivery of the parental product $\mathrm{H} 03$, which has a timeliness of $15 \mathrm{~min}$ itself. The final timeliness required for $\mathrm{H} 05$ over the $\mathrm{H}-\mathrm{SAF}$ area is therefore $30 \mathrm{~min}$.

In the current operational version of PR-OBS-5 at CNMCA, the product is derived by a simple time integration of $\mathrm{H} 03$ rain-rate data (96 samples day ${ }^{-1}$ ) at 15 min intervals over $3,6,12$ and $24 \mathrm{~h}$. The alternative accumulated precipitation product derived from PR-OBS-4 will be implemented when PR-OBS-4 is run routinely at CNMCA.

Considering the design of the precipitation products generating chain (fully described in Sect. 4), any improvement of the parental products of PR-OBS-5 (i.e., PR-OBS-3, which is 


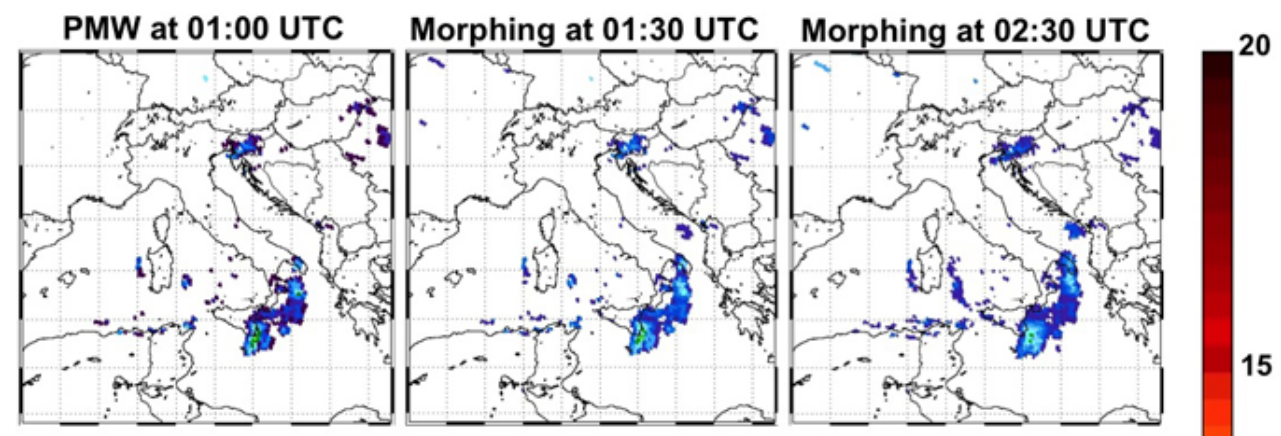

Morphing at 03:30 UTC Morphing at 04:00 UTC Morphing at 04:30 UTC
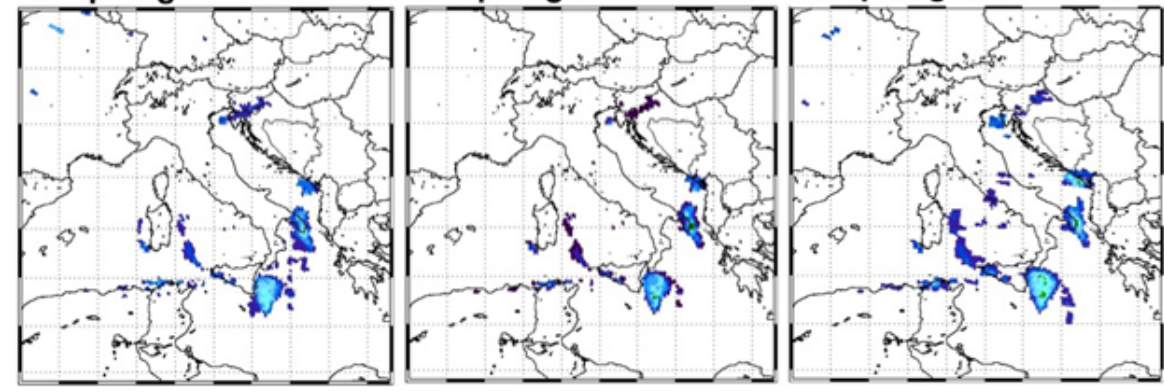

10
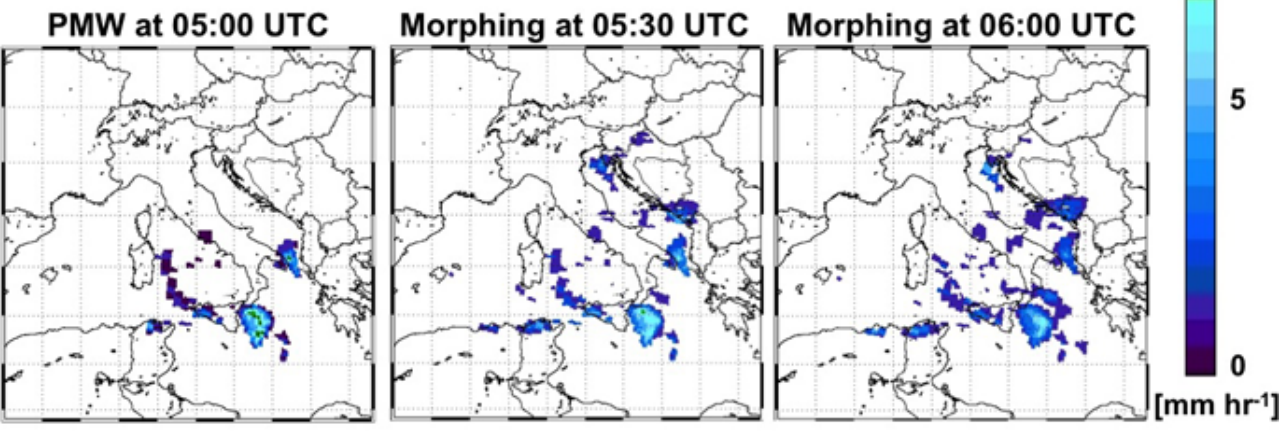

Fig. 4. Example of CMORPH algorithm applied to PMW precipitation intensities retrieved by 183-WSL algorithm of Laviola and Levizzani $(2008,2009,2011)$ for a severe storm over southern Italy during October 2009. PMW rain rates at 01:00 UTC are "morphed" to successive PMW rain-rate estimates at 05:00 UTC. Note that the last two panels, representing CMORPH outputs at 05:30 and 06:00 UTC, respectively, are used to describe CMORPH reconstruction of the rain field between PMW rain rates at 05:00 and 06:30 UTC.

affected, for example, by a bias towards the convective contribution to the precipitation estimate) will have a positive impact on the scores of PR-OBS-5. Moreover, a new version of the PR-OBS-5 algorithm has been designed, which is based on a two-step approach:

1. Use of independent sources of information to take into account the real-time observed precipitation data from rain-gauges and weather radars, to obtain the "combined observed precipitation field"; moreover, introducing a very short-term forecast from numerical weather prediction (NWP) models, acting as first-guess, a real-time objective analysis is performed (analysis step);

2. Real-time correction by means of classical statistical techniques, using the accumulated precipitation analysis field as a proxy observation (correction step) (note that in the current configuration, a simple bias removal algorithm is employed).

Figure 5 shows an example of the difference between the currently operational and the new version of PR-OBS-5 for 17 April 2012. Evidently, the introduction of ancillary information in the new version leads to a difference of the accumulated precipitation in some areas (i.e., southern Adriatic Sea) as large as $3 \mathrm{~mm}$.

\subsection{PR-OBS-6}

PR-OBS-6 provides an instantaneous convective precipitation product $(\mathrm{H} 15)$ at the temporal $(15 \mathrm{~min})$ and spatial $(\sim 8 \mathrm{~km}$ over the H-SAF area) resolution of the MSG SEVIRI, which is based on the combined use of the blendedsatellite rapid-update NRLT technique (see Sect. 3.3) and 


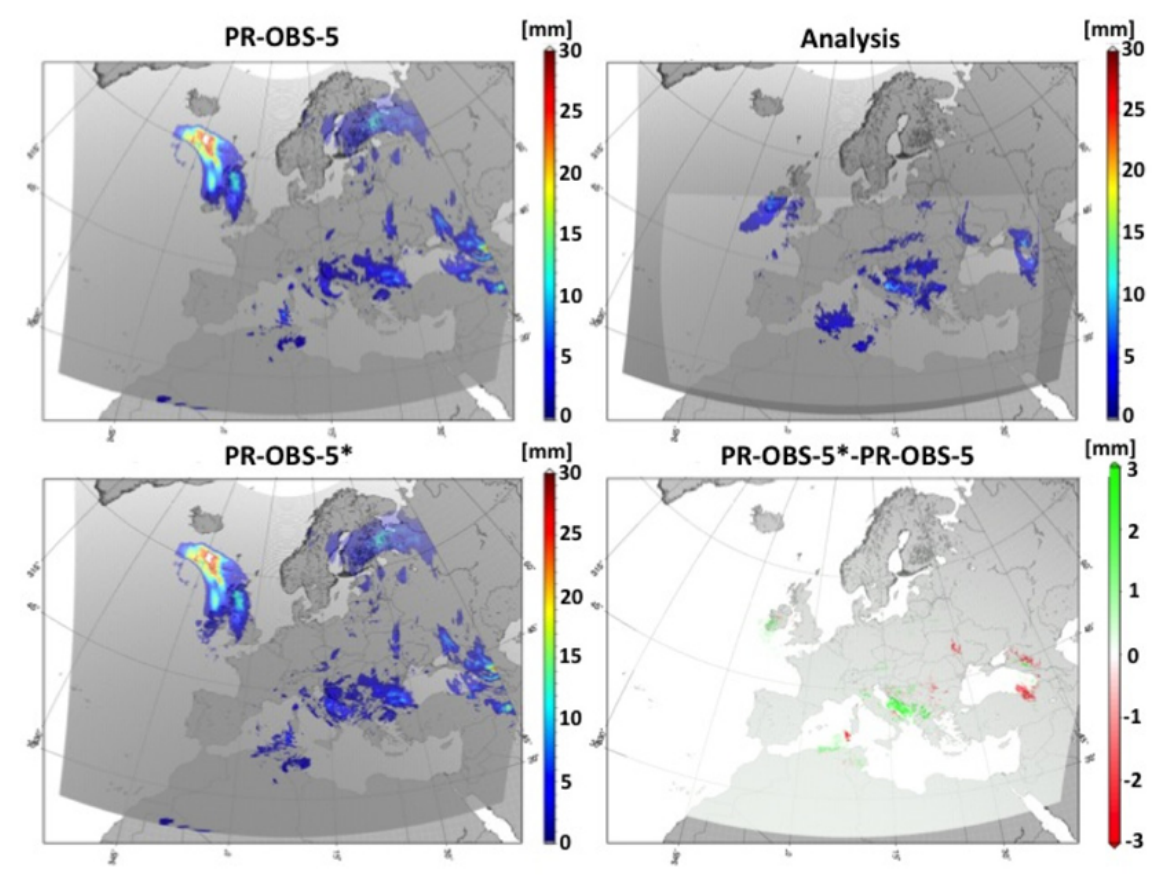

Fig. 5. PR-OBS-5 generated 6-hour accumulated precipitation on 17 April 2012: top left panel shows results from current operational algorithm (PR-OBS-5); top right panel shows results from analysis step; bottom left panel shows results from new version of algorithm (PR-OBS-5*); and bottom right panel shows differences between new and original versions of the algorithm (PR-OBS-5*-PR-OBS-5).

of the DYNAmic NEFOanalysis (NEFODINA) technique (Puca et al., 2005; see also Melfi et al., 2012), which is used for generating a convection mask and for redistributing the initial precipitation estimation, made by PR-OBS- 1 and PR-OBS-2, according to the characteristics of the convective cells.

During the H-SAF DP phase, the performance of the NRLT technique was evaluated by means of a specific validation activity, which demonstrated that a preliminary screening between convective and stratiform clouds has a positive impact in establishing IR-TB-rainfall-rate relationships. Such a screening can be accomplished by means of the NEFODINA technique, which was developed at CNMCA for the detection and classification of convective cloud systems and the monitoring of their life cycles. Specifically, NEFODINA uses a multichannel approach based on the IR window at $10.8 \mu \mathrm{m}$ and the water vapor (WV) absorption bands at $6.2 \mu \mathrm{m}$ and $7.3 \mu \mathrm{m}$ to provide information on convective objects (COs) within cloud systems, from mesoscale convective systems down to single cell thunderstorms. In particular, NEFODINA produces images that identify cells, their development phase (developing/dissolving), and their movement. In addition, these output images are associated with quantitative information on the IR and WV channel TBs, along with the $\mathrm{CO}$ shape, slope index (i.e., the spatial TB gradient), $\mathrm{CO}$ extension area, and $\mathrm{CO}$ mean and minimum TB values, to build a convection mask. An example of the NEFODINA product is presented in Fig. 6, showing that
NEFODINA is an important nowcasting application that can be used to diagnose cloud convective activity and evaluate both its severity and potential development.

It is well known that PMW estimates are affected by a low spatial resolution, which causes significant underestimation of precipitation associated with small-scale convective cells. This problem is tackled by the PR-OBS-6 product, in which NEFODINA is used to improve the convective precipitation retrieval, as compared to PR-OBS-3, both by defining the areas of convection and by redistributing the initial rainfall-rate estimation, made by PR-OBS-1 or PR-OBS-2, according to the spatial variability and extension of the convective cells characterized by the most intense precipitation (see Antonelli et al., 2011). As an example, Fig. 7 shows the difference in $3 \mathrm{~h}$ accumulated precipitation when PR-OBS-3 and PR-OBS- 6 are used as input. The intense convective precipitation that produced a highly damaging flash flood over northeastern Sicily on 1 October 2009 is more evident when PR-OBS-6 is used; in addition, in this case the accumulated precipitation values are much closer to those that had been measured by the rain gauges of the Italian Department of Civil Protection - up to $190--200 \mathrm{~mm}$ in less than $6 \mathrm{~h}$.

During CDOP-2 the geographical region of PR-OBS-6 will be enlarged to include the full disk area. Moreover, the algorithm will be expanded so as to include the new product H50 for estimating convective precipitation from the MTG LI data. 


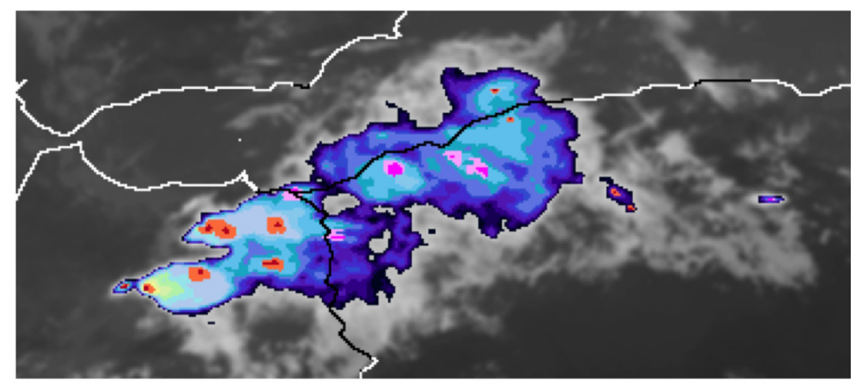

Fig. 6. Example of NEFODINA product from MSG imagery over northwestern Algeria and northeastern Morocco on 29 May 2011 at 17:00 UTC. Blue shades are used to show the cloud system of interest. Dark blue shades are used for low clouds, whereas light blue/yellow shades are used for high clouds. Red shades indicate cloud tops of convective cells in development phase. Pink shades indicate cloud tops of convective cells in dissipation phase. The darkest red and pink shades indicate the most intense convective regions.

\section{H-SAF precipitation product generating chain}

The architecture of the precipitation product generating chain at CNMCA is dedicated to the acquisition of satellite data, data pre-processing and post-processing, and production of precipitation maps. The first configuration of the architecture has been reported by Zauli et al. $(2007,2009)$ and consists of four different parts: (1) reception of satellite data dedicated to precipitation retrievals, (2) map elaboration and dissemination, (3) archiving and monitoring, and (4) web distribution. The architecture has been implemented considering the requirements of products in terms of timeliness, availability, and resolutions. The H-SAF requirements have imposed the use of native formats, without degradation of the information, and the monitoring of the production chain performance. Due to the variety of satellite data that needs to be processed, a redundancy strategy has been adopted to receive polar and geostationary satellite data and to guarantee the success of the acquisition capability.

The acquisition of the satellite data is based on three different systems: (1) direct readout, with a fixed (Meteosat satellites) or tracking (NOAA-POES and EPS-MetOp satellites) L-band antenna installed at CNMCA; (2) EUMETCast, EUMETSAT's broadcasting system based on commercial satellites (http://www.eumetsat.int/website/home/Data/ DataDelivery/EUMETCast/index.html); and (3) file transfer protocol (FTP) over the Internet for receiving DMSP data from the UK Met Office, Exeter, UK. A twin tracking antenna system is installed and functioning at CNMCA, each one with reception capability at L- and X-band. Future satellite systems (as EUMETSAT's Post-EPS) will transmit data to direct readout users at $\mathrm{X}$ frequency, a band already used by the current generation of satellites for complete orbit dumps at polar stations. Data from NOAA-POES

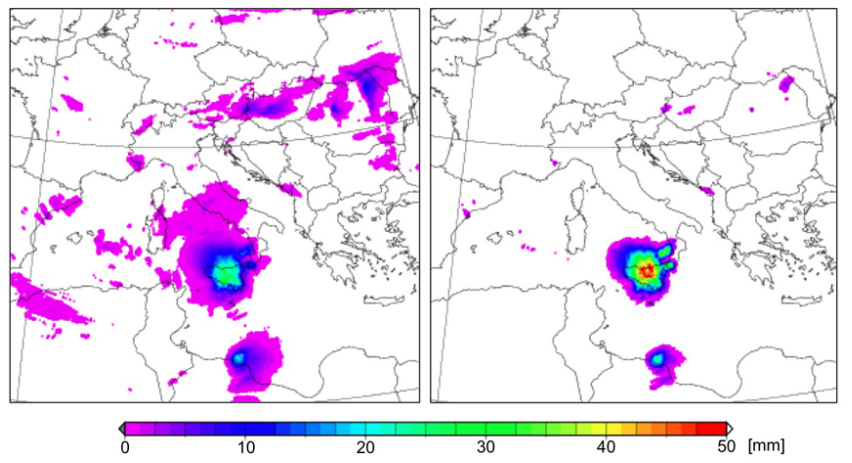

Fig. 7. Accumulated precipitation $(\mathrm{mm})$ for previous three hours on 1 October 2009 at 21:00 UTC, where PR-OBS-3 (left panel) and PR-OBS-6 (right panel) are used for accumulating.

and EUMETSAT-EPS are received both via direct readout, through tracking antennas dedicated to polar satellite acquisition, and EUMETCast. A $2.7 \mathrm{~m}$ diameter antenna, with dual feed for L- and X-band reception, has been prepared to receive data from future polar satellites. The EUMETSAT Advanced Retransmission System (EARS), disseminated by digital video broadcasting via EUMETCast, allows reception in near real time of the NOAA and MetOp data covering Europe and North America (see Fig. 8), but it does not receive the SSMIS data. For this reason, DMSP calibrated and georeferenced data (level L1C) are received via FTP from the UK Met Office, which retransmits global orbit data produced by NOAA. SEVIRI data from MSG are received through EUMETCast. CNMCA generates L1C data from AMSU-A and MHS with the ATOVS and AVHRR Preprocessing Package (AAPP) developed by the SAF for Numerical Weather Prediction (NWP-SAF). These data are passed to the PR-OBS-2 routines for calculating instantaneous surface precipitation rates over the entire H-SAF domain based on the EARS EUMETCast system.

Figure 9 shows the flow diagram of the precipitation product generation. The precipitation product data can be received via EUMETCast but also can be retrieved via FTP. The accessibility of the products via FTP is centralized by CNMCA. The server (ftp.meteoam.it) is accessible to authorized users for product download. The availability of the products is guaranteed in a 3 month "online" window. The $\mathrm{H}$ SAF website (http://hsaf.meteoam.it) provides quick-looks of all products, as well as the relevant scientific and technical documentation and news about workshops and meetings. The "contact us" section of the H-SAF website describes how to retrieve the dataset of interest from the ftp.metoam.it server. After a free registration, the potential user will be contacted via e-mail to perform the download. A detailed report about the performance of service in terms of product availability, archiving, and dissemination is published every six months. Operation reports provide the expected performances and monitor the results of products. 


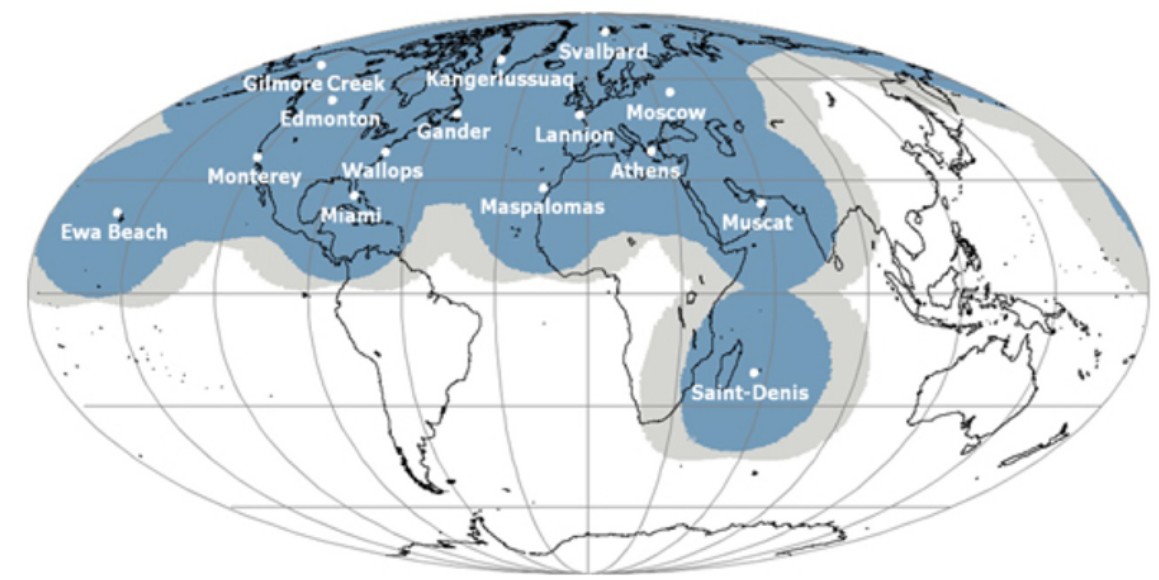

Fig. 8. Map of EUMETSAT Advanced Retransmission System (EARS) stations that receive AMSU/MHS data directly from the overpassing NOAA and MetOp satellites, and retransmit the data to EUMETSAT Headquarters. The color coding indicates the percentage of the actual satellite passes over a given geographical region - i.e., swaths that can be received by the proposed station network. Light grey corresponds to $0-50 \%$ and blue corresponds to $50-100 \%$ (here, $100 \%$ indicates that every time the region is in the field of view of the instrument, then the image data will be received by the network, while $50 \%$ indicates that, on average, every second pass covering the region will be received). (Courtesy of EUMETSAT: http://www.eumetsat.int/website/home/Satellites/CurrentSatellites/Metop/ RegionalDataService/EARSATOVS/index.html.)

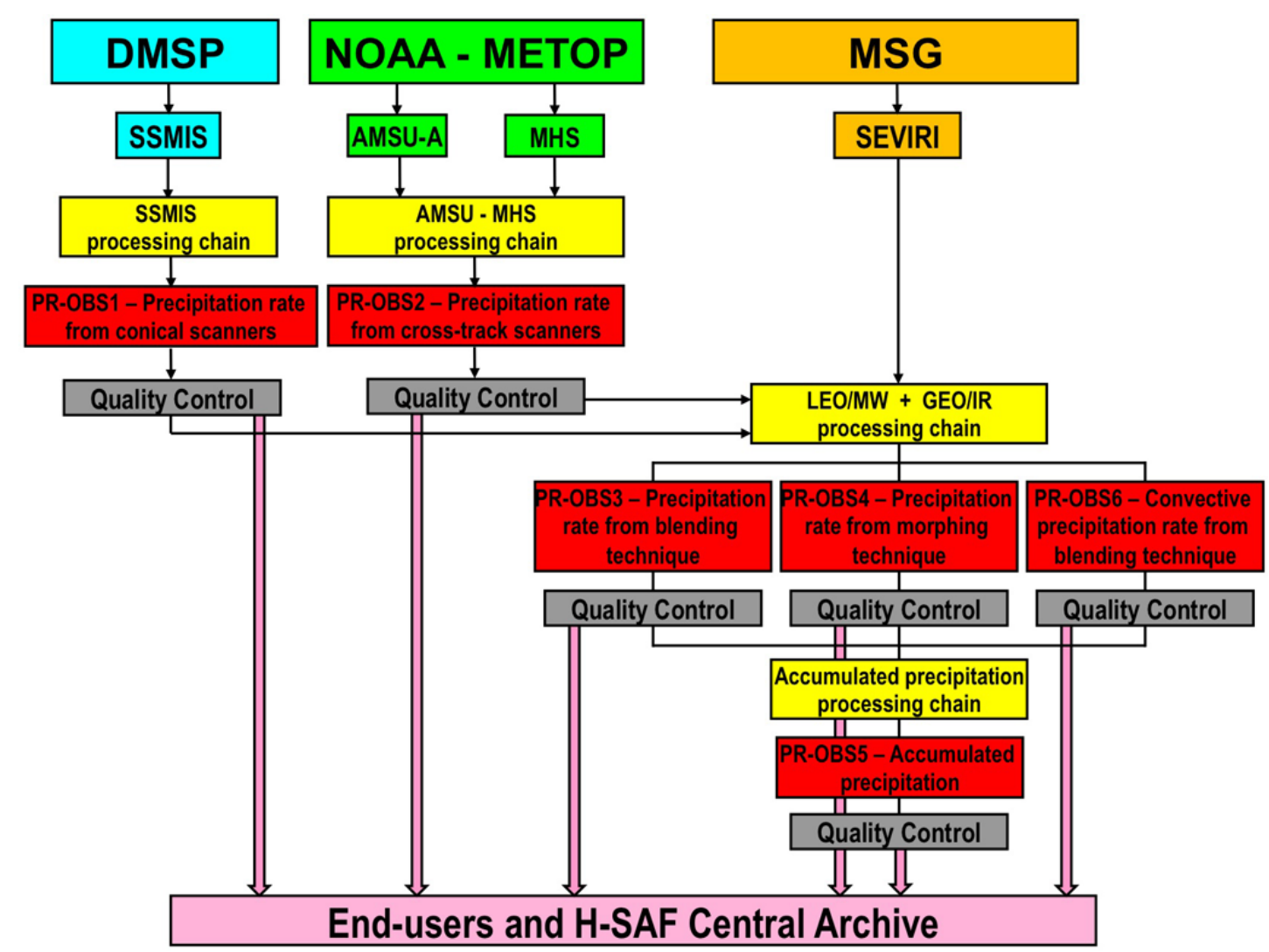

Fig. 9. Flow diagram of the H-SAF precipitation product generating chain. 


\section{H-SAF precipitation product and hydrological validation programs}

Product validation (PV) using independent datasets has been a H-SAF priority since the beginning in order to evaluate the performance of the products, provide error structure information to end users (hydrologists, meteorologists, etc.) and support the product developers. The following is an overview of the precipitation product validation (PPV) activity and of the underlying methodology, while the reader is referred to the companion paper by Puca et al. (2013) for a detailed description together with the presentation and discussion of the results obtained during H-SAF DP and CDOP-1 phases.

For all products generated by the H-SAF project, the PV activity consists of

- monitoring the progress in product quality by means of statistical scores and case study analyses, both based on comparisons between satellite products and corresponding ground data;

- providing validation service to end users by publishing on the H-SAF web page both the statistical scores and the case study analyses;

- providing online quality control to end users by generating near-real-time quality maps;

- monitoring operational features of the products in terms of actual arrival times, timeliness, intelligibility, etc.;

- providing ground data services within the project for algorithm calibration and validation activities;

- investigating H-SAF product impacts on end-user applications such as civil protection activities for emergency management, precipitation event alerts, street monitoring, water balance evaluation, etc.

To this end, a Precipitation Product Validation Group (PPVG) has been established within H-SAF composed of experts (hydrologists, meteorologists, and precipitation ground data experts) from the national meteorological and hydrological institutes of eight countries (Belgium, Bulgaria, Germany, Hungary, Italy, Poland, Slovakia and Turkey), under the coordination of the Italian DPC. The PPVG activity is presently based on a network of 4100 rain gauges and 54 meteorological radars belonging to eight different countries (see Puca et al., 2013) that provide ground data to be used for reference.

Over the years, each institute of the PPVG has developed a specific validation methodology, based on its own knowledge and experience, focused on case study analyses, with the possibility of using ancillary data such as lightning data, SEVIRI images, output of NWP models, and nowcasting products. Nevertheless, the importance of defining a common validation methodology allowing comparison of results obtained by multiple institutes, leading to a more systematic understanding, has become clear since the beginning of the project. The main steps of this methodology have been identified inside the PPVG in collaboration with the product developers (see Puca et al., 2013). The common validation methodology is based on ground data (radar, rain gauge and integrated data) comparisons to produce "large statistics" (multicategorical and continuous). However, since the products to be validated differ in retrieval technique, as well as in space and time resolution, every product needs a specific validation procedure. The main steps of the common validation methodology are (1) ground data (radar and rain gauge) error analysis, (2) point measurement (rain gauge) spatial interpolation, (3) upscaling of radar data to satellite native grid, (4) temporal comparison of satellite- and ground-based precipitation products, and (5) production and evaluation of continuous and multicategorical statistical scores.

As for point (1), differences among rain gauge networks (i.e., temporal sampling, density, availability of heated systems for snow measurements), among radar systems (i.e., time and space resolution, antenna elevation, radar characteristics, retrieval techniques), and of the local geomorphology (i.e., geography, orography, coastlines, etc.) cause the reliability of ground data to vary from area to area, and affect the validation results to varying degrees. For this reason, quality index maps are produced and associated to all ground data. The quality index, which is a function of position and time, is subsumed into a single number ranging between 0 and 1 , and uses all essential information available to quantify the reliability of the ground data to which the index must be associated (see Vulpiani et al., 2008, and Rinollo et al., 2013).

As for point (2), in order to obtain a standard map for comparison with satellite products, the rain gauge measurements are interpolated onto a unique European grid, with grid cells using a $5 \mathrm{~km}$ mesh size. In so doing, three different interpolation techniques have been proposed and tested: (1) a Barnes method (Barnes, 1964), (2) a Kriging method, and (3) a GRISO (Random Generator of Space Interpolations from Uncertain Observations) method (see Pignone et al., 2010), which is an improved Kriging-based method implemented by the Italian CIMA (International Centre on Environmental Monitoring) Research Foundation. Results show the best performance arises using the GRISO method, which has thus been adopted.

As for point (3), the PPVG members decided together with the product developers to validate each product using its native grid as the reference grid. Thus, the radar data, which always have resolutions higher than the product resolution, are always upscaled to the product grid. Alternatively, for the interpolated rain gauge data, when product resolutions are on the order of $5 \mathrm{~km}$ (i.e., for LEO-GEO combined products) a nearest-neighbor matching is performed. For coarser satellite product resolutions (i.e., for LEO-only products), the interpolated rain gauge data are again upscaled. As an example, 

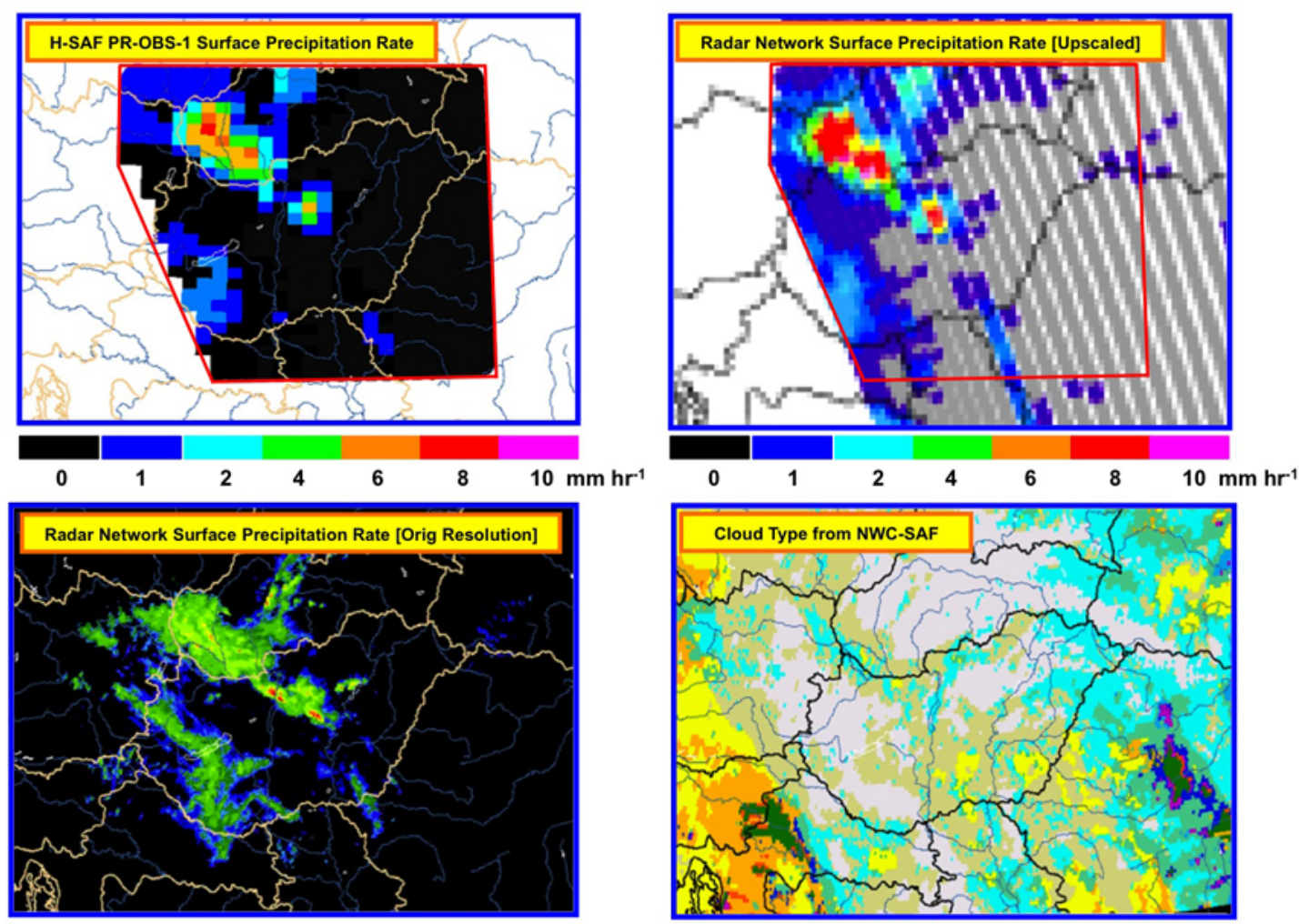

Fig. 10. Various sources of surface precipitation-rate products plus a cloud-type product over Hungary on 5 May 2010 at 16:29 UTC: HSAF's PR-OBS-1 surface precipitation rate (upper left panel); corresponding Hungarian operational radar network surface precipitation rate in upscaled format (upper right panel); corresponding Hungarian operational weather radar network surface precipitation rate in original resolution format (lower left panel); and corresponding cloud type from NWC-SAF (lower right panel). Note upper panels use the same precipitation rate color bar ranging from 0 to $10 \mathrm{~mm} \mathrm{~h}^{-1}$, whereas a different precipitation rate color bar is used for lower left panel (not shown). (Cloud type key also not shown.)

Fig. 10 shows a PR-OBS-1 image and the corresponding radar data both at the original and upscaled resolutions.

As for points (4) and (5), at the end of the validation procedure statistical scores are calculated on a monthly basis for the satellite-radar data pairs for land, sea and coastal pixels separately. Several statistical scores are considered that can be identified and grouped as continuous statistics, multicategory statistics (using three and five precipitation classes for the instantaneous and accumulated products, respectively), and probability distribution functions (thirty distribution classes of satellite and radar data). Every institute calculates the statistics over their pertinent areas following the common validation methodology. Then, at the end of the line, an overall statistic for the entire H-SAF area is calculated by DPC, which acts as the coordinating institute (see Puca et al., 2013, for a sample of results).

It is foreseen that during CDOP-2, with the generation of satellite products for the MSG full disk and collaboration with international groups and programs (such as IPWG, TRMM and GPM), PPV activity will be extended to available sites in Africa with experts from non-European countries (in particular, from Africa and the Americas) participating in the PPVG. Collaboration with the IPWG will involve comparing different validation methodologies and introducing IPWG precipitation products into the H-SAF validation procedures. By the same token, during CDOP-2 the $\mathrm{H}-\mathrm{SAF}$ validation infrastructure will be used for validation and quality assessment of precipitation products developed by or shared with other SAFs, such as NWC-SAF and CMSAF. The PPVG also plans to use data from satellite-borne radars (from the TRMM PR over the African area and then from the DPR onboard the GPM Core Satellite over both the $\mathrm{H}-\mathrm{SAF}$ and African areas) as reference for the validation activity.

Finally, besides the PPV program, H-SAF includes a hydrological validation (HV) program aiming at independently assessing the benefit of using the various H-SAF satellitederived products in practical hydrological applications. The final goal is to encourage the utilization of H-SAF products by national hydrological services and improve the use of satellite data within hydrological models for near-real-time monitoring of runoff and the hydrological states of basins, water management, low-flow forecasting, and flood risk forecasting - taking into account the importance of providing 
information redundant with respect to ground observations, since these may be unavailable in extreme or catastrophic cases due to damage to the local measuring equipment and/or data links.

In this regard, satellite products (in particular, precipitation products) are being used as input to a number of hydrological models ( 13 of them in all) and impact and validation studies on several test sites ( 21 of them in all), each with different characteristics and sizes, in eight European countries (Belgium, Bulgaria, Finland, Germany, Italy, Poland, Slovakia and Turkey). These activities are being performed under the coordination of the Polish IMGW. The preliminary $\mathrm{HV}$ activity that has been carried out during DP and CDOP1 has shown that the H-SAF satellite precipitation products may still have limited accuracy when incorporated directly into the hydrological models. That is why during CDOP-2 these products must be used, with their wide and continuous spatial distribution, to improve point ground data from rain gauges and/or radar data by means of satellite-rain-gaugeradar blending procedures. In this manner, the blended data can be used as input data for hydrological models and validated in the same way as the original H-SAF products. It is tacitly understood that this will make the precipitation products more applicable in operational hydrology.

\section{Summary and conclusions}

We have presented an overview and explanation of the EUMETSAT Satellite Application Facility on Support to Operational Hydrology and Water Management, which is the main European effort concerning use of satellite precipitation data operationally. While other SAFs produce precipitation products, the H-SAF focus is largely on precipitation products from available LEO and GEO satellites using both passive-microwave and infrared data. In fact, H-SAF generates operational precipitation products that are useful for not only hydrological applications, but also for many other scientific research applications because they are based on a suite of advanced and ever-improving algorithms described herein.

$\mathrm{H}$-SAF has adopted, from its inception, a validation strategy which is now growing and reaching a critical mass necessary to validate operational meteorology, hydrology and climate products. Specifically, H-SAF includes both a product validation program and a hydrological validation program, which involve several countries. These programs have been shown to be instrumental in evaluating and improving $\mathrm{H}-$ SAF precipitation products, as well as for assessing product usefulness in mitigating against hazards due to floods, landslides and avalanches, as well as evaluation of water resources. At present, H-SAF is the only collaborative program in the meteorological and hydrological communities that has managed to create an extensive ground-based reference data network by sharing data from eight different countries and treating them with the same methodology.
Like the other seven SAFs, H-SAF has just entered the second part of the Continuous Development and Operations Phase (2012-2017), and therefore has several years ahead to release advanced products and work with the next generation of LEO and GEO satellites, particularly with EUMETSAT's Post-EPS and MTG satellites.

$\mathrm{H}-\mathrm{SAF}$ is an active member of the International Precipitation Working Group, while the H-SAF algorithms are part of the IPWG inventory of operational satellite precipitation retrieval tools as a EUMETSAT contribution. The international activity of $\mathrm{H}-\mathrm{SAF}$ is conducted via a new coordination body within EUMETSAT, i.e., the Precipitation Science Advisory Group, which has been established for ensuring an adequate level of coordination of the activities between SAFs - i.e., especially between H-SAF, the Nowcasting SAF and the Climate Monitoring SAF. Finally, H-SAF is the only Europewide entity that can devise a long-term partnership involving continental precipitation within current international programs, such as the NASA-JAXA Global Precipitation Measurement mission (an international effort designed to obtain $3 \mathrm{~h}$ coverage of precipitation over the globe). In so doing, various $\mathrm{H}-\mathrm{SAF}$ precipitation algorithms and products will be developed in the near future for exploitation with measurements from the GPM Core Observatory planned for launch in 2014.

Table A1. Acronyms.

\begin{tabular}{ll}
\hline AAPP: & ATOVS and AVHRR Pre-processing Package \\
AMSU: & Advanced Microwave Sounding Unit \\
ANN: & Artificial Neural Network \\
ATOVS: & Advanced TIROS Operational Vertical Sounder \\
AVHRR: & Advanced Very High Resolution Radiometer \\
CDOP: & Continuous Development and Operations Phase \\
CDRD: & Cloud Dynamics and Radiation Database \\
CGMS: & Coordination Group for Meteorological Satel- \\
& lites \\
CIMA: & Italian International Centre on Environmental \\
& Monitoring \\
CMORPH: & CPC Morphing Technique \\
CM-SAF: & Satellite Application Facility on Climate Moni- \\
& toring \\
CNMCA: & National Center of Aeronautical Meteorology \\
& and Climatology \\
CNR: & Italian National Research Council \\
CO: & Convective Object \\
CPC: & Climate Prediction Center \\
CRD: & Cloud Radiation Database \\
CRM: & Cloud Resolving Model \\
DMSP: & Defense Meteorological Satellite Program \\
DP: & Development Phase \\
DPC: & Italian Department of Civil Protection \\
DPR: & Dual-frequency Precipitation Radar \\
DTH: & Dynamical-Thermodynamical-Hydrological \\
ECMWF: & European Centre for Medium-Range Weather \\
& Forecasts \\
EARS: & EUMETSAT Advanced Retransmission System \\
\hline &
\end{tabular}




\begin{tabular}{|c|c|}
\hline EC: & European Commission \\
\hline ECT: & Equatorial Crossing Time \\
\hline EPS: & EUMETSAT Polar System \\
\hline ESA: & European Space Agency \\
\hline EU: & European Union \\
\hline EUMETSAT: & $\begin{array}{l}\text { European Organisation for the Exploitation of } \\
\text { Meteorological Satellites }\end{array}$ \\
\hline FCI: & Flexible Combined Imager \\
\hline FMI: & Finnish Meteorological Institute \\
\hline FTP: & File Transfer Protocol \\
\hline GEO: & Geostationary Earth Orbit \\
\hline GMES: & $\begin{array}{l}\text { Global Monitoring for Environment and Secu- } \\
\text { rity }\end{array}$ \\
\hline GMI: & GPM Microwave Imager \\
\hline GPM: & Global Precipitation Measurement \\
\hline GRISO: & $\begin{array}{l}\text { Random Generator of Space Interpolations } \\
\text { from Uncertain Observations }\end{array}$ \\
\hline H-SAF: & $\begin{array}{l}\text { Satellite Application Facility on Support to Op- } \\
\text { erational Hydrology and Water Management }\end{array}$ \\
\hline HV: & Hydrological Validation \\
\hline IFOV: & Instantaneous Field-of-View \\
\hline IMGW: & $\begin{array}{l}\text { Polish Institute of Meteorology and Water Man- } \\
\text { agement }\end{array}$ \\
\hline IOP: & Initial Operations Phase \\
\hline IPWG: & International Precipitation Working Group \\
\hline IR: & InfraRed \\
\hline ISAC: & Institute of Atmospheric Sciences and Climate \\
\hline ITAF: & Italian Air Force \\
\hline JAXA: & Japan Aerospace Exploration Agency \\
\hline LEO: & Low-Earth-Orbiting \\
\hline LI: & Lightning Imager \\
\hline LST: & Local Solar Time \\
\hline MetOp: & Meteorological Operational \\
\hline MHS: & Microwave Humidity Sounder \\
\hline MM5: & Mesoscale Model-5 \\
\hline MSG: & Meteosat Second Generation \\
\hline MTG: & Meteosat Third Generation \\
\hline MW: & MicroWave \\
\hline NASA: & National Aeronautics and Space Administration \\
\hline NCAR: & National Center for Atmospheric Research \\
\hline NEFODINA: & DYNAmic NEFOanalysis \\
\hline NMS: & Non-hydrostatic Modeling System \\
\hline NOAA: & $\begin{array}{l}\text { National Oceanic and Atmospheric Administra- } \\
\text { tion }\end{array}$ \\
\hline NRL: & Naval Research Laboratory \\
\hline NRLT: & NRL Technique \\
\hline NWC-SAF: & $\begin{array}{l}\text { Satellite Application Facility on Support to } \\
\text { Nowcasting and Very Short Range Forecasting }\end{array}$ \\
\hline NWP: & Numerical Weather Prediction \\
\hline NWP-SAF: & $\begin{array}{l}\text { Satellite Application Facility for Numerical } \\
\text { Weather Prediction }\end{array}$ \\
\hline OSCAR: & $\begin{array}{l}\text { Observing Systems Capability Analysis and } \\
\text { Review Tool }\end{array}$ \\
\hline PMW: & Passive Microwave \\
\hline PNPR: & $\begin{array}{l}\text { Passive-microwave Neural-network Precipita- } \\
\text { tion Retrieval }\end{array}$ \\
\hline POES: & $\begin{array}{l}\text { Polar-orbiting Operational Environmental } \\
\text { Satellites }\end{array}$ \\
\hline PPV: & Precipitation Product Validation \\
\hline PPVG: & Precipitation Product Validation Group \\
\hline
\end{tabular}

\begin{tabular}{ll}
\hline PR: & Precipitation Radar \\
P-SAG: & Precipitation Science Advisory Group \\
PSU: & Pennsylvania State University \\
PV: & Product Validation \\
RTM: & Radiative Transfer Model \\
SAF: & Satellite Application Facility \\
SEVIRI: & Spinning Enhanced Visible and InfraRed Im- \\
& ager \\
SMA: & Italian Aeronautical Meteorological Service \\
SSM/I: & Special Sensor Microwave Imager \\
SSMIS: & Special Sensor Microwave Imager/Sounder \\
TB: & Brightness Temperature \\
TIROS: & Television InfraRed Observation Satellite \\
TMI: & TRMM Microwave Imager \\
TRMM: & Tropical Rainfall Measuring Mission \\
TSMS: & Turkish State Meteorological Service \\
USAM: & General Office for Air Space and Meteorology \\
UTC: & Universal Time Coordinated \\
WMO: & World Meteorological Organization \\
WV: & Water Vapor \\
ZAMG: & Austrian Central Institution for Meteorology \\
& and Geodynamics \\
\hline
\end{tabular}

Acknowledgements. We wish to thank Roberto Sorani and Bizzarro Bizzarri who were among the main promoters for a SAF on support to hydrology, and then coordinated the H-SAF activities during its Development Phase. A. Mugnai, D. Casella, S. Dietrich, G. Panegrossi and P. Sanò would also like to thank Eric A. Smith and Gregory J. Tripoli, with whom the CDRD approach has been conceived and developed. Finally, we wish to thank the two anonymous reviewers for their helpful comments and suggestions. Over the years, the CNR-ISAC participation in the H-SAF project has been supported not only by EUMETSAT, but also by several Italian and European agencies through a series of national and international projects - i.e., (1) by the Italian Department of Civil Protection (DPC) through the Operational Agreement DPC-ISAC; (2) by the European Community Initiative INTERREG III-B ARCHIMED through the project "Weather Risk Reduction in the Central and Eastern Mediterranean" (RISKMED); (3) by the Italian FISR-MIUR Programme "Sustainable Development and Climate Changes" through the project "Aerosol Effects on Clouds and Climate" (AEROCLOUDS); (4) by the Italian Space Agency (ASI) through the pilot project "Civil Protection from Floods: The Nowcasting"; and (5) by the European Commission through two different projects - the 6th Framework Programme project "Observation, Analysis and Modeling of Lightning Activity in Thunderstorms, for use in Short Term Forecasting of Flash Floods" (FLASH) for the Rome group (A. Mugnai, D. Casella, S. Dietrich, F. Di Paola, G. Panegrossi and P. Sanò), and the 7th Framework Programme FP7-2010-1.1-04 GMES project "Global Water Scarcity Information Service” (GLOWASIS), GA No. 262255, for the Bologna group (V. Levizzani, E. Cattani and S. Laviola).

Edited by: G. Boni

Reviewed by: two anonymous referees 


\section{References}

Antonelli, P., Puca, S., Zauli, F., Bennartz, R., De Leonibus, L., Feltz, W., and Woolf, H.: Validation of satellite rain rate estimation with ground-based observing systems, in: Integrated Ground-Based Observing Systems, Application for Climate, Meteorology and Civil Protection, edited by: Cimini, D., Marzano, F., and Visconti, G., Springer-Verlag, Berlin - Heidelberg, Germany, 241-278, 2011.

Barnes, S. L.: A technique for maximizing details in numerical weather map analysis, J. Appl. Meteor., 3, 396-409, 1964.

Calheiros, R. V. and Zawadzki, I. I.: Reflectivity rain-rate relationship for radar hydrology in Brazil, J. Clim. Appl. Meterol., 26, 118-132, 1987.

Casella, D., Panegrossi, G., Sanò, P., Mugnai, A., Smith, E. A., Tripoli, G. J., Dietrich, S., Formenton, M., Di Paola, F., Leung, H. W.-Y., and Mehta, A. V.: Transitioning from CRD to CDRD in Bayesian retrieval of rainfall from satellite passive microwave measurements, Part 2: Overcoming database profile selection ambiguity by consideration of meteorological control on microphysics, IEEE Trans. Geosci. Remote Sens., in press, 2013.

Chen, F. W. and Staelin, D. H.: AIRS/AMSU/HSB precipitation estimates, IEEE Trans. Geosci. Remote Sens., 41, 410-417, 2003.

Dudhia, J.: A nonhydrostatic version of the Penn State-NCAR Mesoscale Model: Validation tests and simulation of an Atlantic cyclone and cold front, Mon. Weather Rev., 121, 1493-1513, 1993.

Goldberg, M. D., Crosby, D. S., and Zhou, L.: The limb adjustment of AMSU-A observations: Methodology and validation, J. Appl. Meteor., 40, 70-83, 2001.

Grell, G., Dudhia, J., and Stauffer, D. R.: A Description of the Fifth Generation Penn State/NCAR Mesoscale Model (MM5), NCAR Technical Note NCAR/TN-398+STR, National Center for Atmospheric Research, Boulder, Colorado, USA, 121 pp., 1994.

Grody N., Weng, F., and Ferraro, R.: Application of AMSU for obtaining hydrological parameters, in: Microwave Radiometry and Remote Sensing of the Earth's Surface and Atmosphere, edited by: Pampaloni, P. and Paloscia, S., VSP 2000, 339-352, 2000.

Joyce, R. J., Janowiak, J. E., Arkin, P. A., and Xie, P.: CMORPH: A method that produces global precipitation estimates from passive microwave and infrared data at high spatial and temporal resolution, J. Hydromet., 5, 487-503, 2004.

Laviola, S. and Levizzani, V.: Rain retrieval using $183 \mathrm{GHz}$ absorption lines, in: Proceedings of the 10th IEEE Specialist Meeting on Microwave Radiometry and Remote Sensing of the Environment (MicroRad 2008), Firenze, Italy, 11-14 March 2008, doi:10.1109/MICRAD.2008.4579505, 2008.

Laviola, S. and Levizzani, V.: Observing precipitation by means of water vapor absorption lines: A first check of the retrieval capabilities of the 183-WSL rain retrieval method, Italian J. Remote Sens., 41, 39-49, 2009.

Laviola, S. and Levizzani, V.: The 183-WSL fast rain rate retrieval algorithm, Part I: Retrieval design, Atmos. Res., 99, 443-461, 2011.

Melfi, D., Zauli, F., Biron, D., Vocino, A., and Sist, M.: The impact of NEFODINA convective clouds identification in the rain rate retrieval of H-SAF, Proceedings of the 2012 EUMETSAT Meteorological Satellite Conference, Sopot, Poland, 3-7 September 2012, EUMETSAT P.61, 7 pp., 2012.
Mugnai, A., Smith, E. A., Tripoli, G. J., Bizzarri, B., Casella, D., Dietrich, S., Di Paola, F., Panegrossi, G., and Sanò, P.: CDRD and PNPR satellite passive microwave precipitation retrieval algorithms: EuroTRMM/EURAINSAT origins and $\mathrm{H}-$ SAF operations, Nat. Hazards Earth Syst. Sci., 13, 887-912, doi:10.5194/nhess-13-887-2013, 2013.

Panegrossi, G., Dietrich, S., Marzano, F. S., Mugnai, A., Smith, E. A., Xiang, X., Tripoli, G. J., Wang, P. K., and Poiares Baptista, J. P. V.: Use of cloud model microphysics for passive microwave-based precipitation retrieval: Significance of consistency between model and measurement manifolds, J. Atmos. Sci., 55, 1644-1673, 1998.

Panegrossi, G., Casella, D., Cattani, E., Dietrich, S., Laviola, S., Levizzani, V., Mugnai, A., Sanò, P., Biron, D., De Leonibus, L., Melfi, D., Rosci, P., Vocino, A., Zauli, F., Milani, L., Porcù, F., Puca, S., Rinollo, A., and Gattari, F.: Precipitation products from the Hydrology SAF, Proceedings of the 2012 EUMETSAT Meteorological Satellite Conference, Sopot, Poland, 3-7 September 2012, EUMETSAT P.61, 8 pp., 2012.

Pignone, F., Rebora, N., Silvestro, F., and Castelli, F.: GRISO - Rain, CIMA Research Foundation, Savona, Italy, Operational Agreement 778/2009 DPC-CIMA, Year-1 Activity Report 272/2010, 353 pp., 2010 (in Italian).

Puca, S., De Leonibus, L., Zauli, F., Rosci, P., and Biron, D.: Improvements on numerical "object" detection and nowcasting of convective cell with the use of SEVIRI data (IR and WV channels) and neural techniques, The World Weather Research Programme's Symposium on Nowcasting and Very Short Range Forecasting, Tolouse, France, 5-9 September 2005.

Puca, S., Baguis, P., Campione, E., Ertürk, A., Gabellani, S., Iwański, R., Jurašek, M., Kaňák, J., Kerényi, J., Koshinchanov, G., Kozinarova, G., Krahe, P., Łapeta, B., Lábó, E., Milani, L., Okon, L., Öztopal, A., Pagliara, P., Pignone, F., Porcù, F., Rachimow, C., Rebora, N., Rinollo, A., Roulin, E., Sönmez, İ., Toniazzo, A., Vulpiani, G., Biron, D., Casella, D., Cattani, E., Dietrich, S., Laviola, S., Levizzani, V., Melfi, D., Mugnai, A., Panegrossi, G., Petracca, M., Sanò, P., Zauli, F., Rosci, P., and De Leonibus, L.: The validation service of the Hydrological SAF geostationary and polar satellite precipitation products, Nat. Hazards Earth Syst. Sci., in press, 2013.

Rinollo, A., Vulpiani, G., Puca, S., Pagliara, P., Kaňák, J., Lábó, E., Okon, L., Roulin, E., Baguis, P., Cattani, E., Laviola, S., and Levizzani, V.: Definition and impact of a quality index for radarbased reference measurements in the H-SAF precipitation product validation, Nat. Hazards Earth Syst. Sci., in press, 2013.

Rosenkranz, P.: Rapid radiative transfer model for AMSU/HSB channels, IEEE Trans. Geosci. Rem. Sens., 41, 362-368, 2003.

Sanò, P., Casella, D., Mugnai, A., Schiavon, G., Smith, E. A., and Tripoli, G. J.: Transitioning from CRD to CDRD in Bayesian retrieval of rainfall from satellite passive microwave measurements, Part 1: Algorithm description and testing, IEEE Trans. Geosci. Remote Sens., in press, 2013.

Smith, E. A., Leung, H. W.-Y., Elsner, J. B., Mehta, A. V., Tripoli, G. J., Casella, D., Dietrich, S., Mugnai, A., Panegrossi, G., and Sanò, P.: Transitioning from CRD to CDRD in Bayesian retrieval of rainfall from satellite passive microwave measurements: Part 3 - Identification of optimal meteorological tags, Nat. Hazards Earth Syst. Sci., 13, 1185-1208, doi:10.5194/nhess-13-11852013, 2013. 
Surussavadee, C. and Staelin, D. H.: Global millimeter-wave precipitation retrievals trained with a cloud-resolving numerical weather prediction model, Part I: Retrieval design. IEEE Trans. Geosci. Remote Sens., 46, 99-108, 2008a.

Surussavadee, C. and Staelin, D. H.: Global millimeter-wave precipitation retrievals trained with a cloud-resolving numerical weather prediction model, Part I: Performance evaluation, IEEE Trans. Geosci. Remote Sens., 46, 109-118, 2008 b.

Surussavadee, C. and Staelin, D. H.: Satellite retrievals of Arctic and Equatorial rain and snowfall rates using millimeters wavelengths, IEEE Trans. Geosci. Remote Sens., 47, 3697-3707, 2009.

Torricella, F., Levizzani, V., and Turk, F. J.: Application of a blended MW-IR rainfall algorithm to the Mediterranean, in: Measuring Precipitation from Space: EURAINSAT and the Future, edited by: Levizzani, V., Bauer, P., and Turk, F. J., Advances in Global Change Research, Volume 28, Springer, Dordrecht, The Netherlands, 497-508, 2007.

Tripoli, G. J.: A nonhydrostatic model designed to simulate scale interaction, Mon. Weather Rev., 120, 1342-1359, 1992.

Tripoli, G. J. and Smith, E. A.: Introducing variable-step topography (VST) coordinates within dynamically constrained Nonhydrostatic Modeling System (NMS), Part 1: VST formulation within NMS host model framework, Dyn. Atmos. Oceans, submitted, 2013a.

Tripoli, G. J. and Smith, E. A.: Introducing variable-step topography (VST) coordinates within dynamically constrained Nonhydrostatic Modeling System (NMS), Part 2: VST performance on orthodox obstacle flows, Dyn. Atmos. Oceans, submitted, 2013b.
Turk, F. J. and Miller, S. D.: Toward improving estimates of remotely-sensed precipitation with MODIS/AMSR-E blended data techniques, IEEE Trans. Geosci. Remote Sens., 43, 10591069, 2005.

Turk, F. J., Hawkins, J., Smith, E. A., Marzano, F. S., Mugnai, A., and Levizzani, V.: Combining SSM/I, TRMM and infrared geostationary satellite data in a near-realtime fashion for rapid precipitation updates: advantages and limitations, Proceedings of the 2000 EUMETSAT Meteorological Satellite Data Users' Conference, 452-459, 2000.

Vulpiani, G., Tabary, P., Chatelet, J. P. D., and Marzano, F. S.: Comparison of advanced radar polarimetric techniques for operational attenuation correction at C band, J. Atmos. Oceanic Technol., 25, 1118-1135, 2008.

Zauli, F., Biron, D., and Melfi, D.: The precipitation products generation chain for the EUMETSAT Hydrological Satellite Application Facility at C.N.M.C.A., Proceedings of the Joint 2007 EUMETSAT Meteorological Satellite Conference and the 15th Satellite Meteorology \& Oceanography Conference of the American Meteorological Society, Amsterdam, The Netherlands, 2428 September 2007, EUMETSAT P.50, 2007.

Zauli, F., Biron, D., and Melfi, D.: The precipitation products generation chain for the EUMETSAT Hydrological Satellite Application Facility at C.N.M.C.A., Proceedings of the 2009 EUMETSAT Meteorological Satellite Conference, Bath, United Kingdom, 21-25 September 2009, EUMETSAT P.55, 2009. 